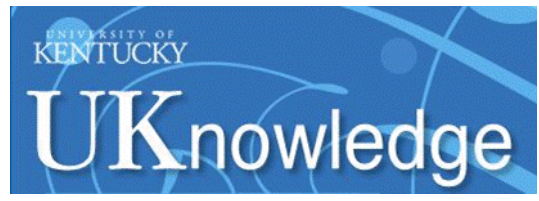

University of Kentucky

UKnowledge

\title{
$5-2018$
}

\section{The Antitrust Duty to Charge Low Prices}

Ramsi Woodcock

University of Kentucky College of Law, ramsi.woodcock@uky.edu

Follow this and additional works at: https://uknowledge.uky.edu/law_facpub

Part of the Antitrust and Trade Regulation Commons

Right click to open a feedback form in a new tab to let us know how this document benefits you.

\section{Repository Citation}

Woodcock, Ramsi, "The Antitrust Duty to Charge Low Prices" (2018). Law Faculty Scholarly Articles. 632. https://uknowledge.uky.edu/law_facpub/632

This Article is brought to you for free and open access by the Law Faculty Publications at UKnowledge. It has been accepted for inclusion in Law Faculty Scholarly Articles by an authorized administrator of UKnowledge. For more information, please contact UKnowledge@lsv.uky.edu. 


\section{The Antitrust Duty to Charge Low Prices}

\section{Notes/Citation Information}

Ramsi A. Woodcock, The Antitrust Duty to Charge Low Prices, 39 Cardozo L. Rev. 1741 (2018). 


\title{
The ANTITRUst Duty TO CHARge LOW PRICES
}

\author{
Ramsi A. Woodcock $\dagger$
}

Over the past forty years, antitrust has come to embrace a goal of consumer welfare maximization that cannot be achieved solely through condemnation of collusive or exclusionary conduct. To address cases in which firms achieve the power to raise prices and harm consumers without engaging in collusive or exclusionary conduct, antitrust should impose a general duty on businesses to charge a price no higher than economic cost. Courts would not need to set prices to enforce this duty, because violations would be punishable only by nominal damages, and shame, rather than by an injunction setting a reasonable price. Although the effect of this duty on prices and consumer welfare is likely to be modest, the nonlinear relationship between price and total welfare suggests that a substantial improvement in total welfare could result.

\section{TABLE OF CONTENTS}

INTRODUCTION 1742

I. A Low PRICING DUTY AS A LAW-AND-EConomics PRoJeCt.............................. 1750

II. The Gap BETWEEN END AND MEANS In CONTEMPORARy ANTITRUST ............ 1755

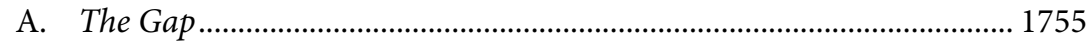

B. Objections to Filling the Gap ..................................................................... 1760

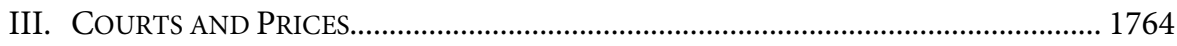

A. The Judicial Setting of Prices .................................................................. 1764

B. The Judicial Review of Prices .................................................................. 1766

1. Outside Antitrust......................................................................... 1766

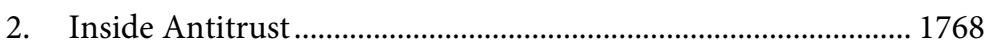

IV. An Antitrust Duty to Charge Cost ...................................................... 1770

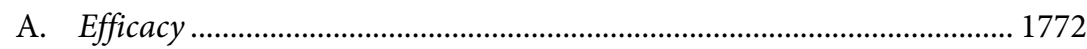

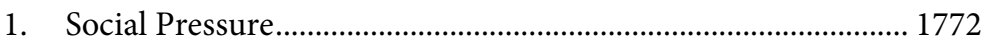

2. The Nonlinearity of Welfare in Prices ...................................... 1772

B. Enforcement Costs................................................................................. 1774

$\dagger$ Assistant Professor, University of Kentucky College of Law. 
C. The Legality of Nominal Damages and Fee Stasis................................. 1777

1. Nominal Damages ........................................................................... 1777

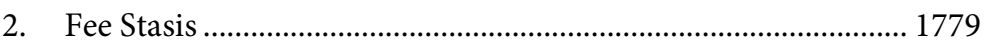

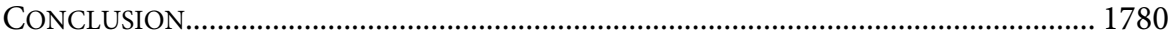

\section{INTRODUCTION}

Between 2007 and 2016, Mylan Pharmaceuticals raised the price of the EpiPen, a life-saving device for allergy sufferers, from about $\$ 100$ to $\$ 600$ for a two-pack.1 A consumer aware that antitrust's mission is to protect the welfare of consumers might have expected antitrust enforcers to leap into action, obtaining an injunction reducing the price, and perhaps jail time for senior management.2 Instead, it was the legislative branch of government that responded, opening investigations and shaming Mylan's CEO at hearings. ${ }^{3}$ Only then did the company eventually reduce the price of the device by half. ${ }^{4}$

The pattern was the same in other recent instances of price gouging by drug makers. When Turing Pharmaceuticals raised the price of a drug from $\$ 13.50$ to $\$ 750$ per tablet, for example, Congress excoriated its CEO in hearings, but antitrust did nothing. ${ }^{5}$ After news reports that several drug makers, including Valeant Pharmaceuticals, had embraced price gouging as a business model, the President promised to force prices down, but antitrust again did nothing. ${ }^{6}$

1 Andrew Pollack, Mylan Raised EpiPen's Price Before the Expected Arrival of a Generic, N.Y. TIMES (Aug. 24, 2016), https://www.nytimes.com/2016/08/25/business/mylan-raisedepipens-price-before-the-expected-arrival-of-a-generic.html.

2 See 15 U.S.C. $\$ \$ 1,2$ (2012) (Sherman Act provisions authorizing criminal penalties for conduct that restrains trade or monopolizes); 15 U.S.C. $\$ 4$ (authorizing equitable relief for the government for violations of the Sherman Act); 15 U.S.C. $\$ 26$ (authorizing injunctive relief for private plaintiffs for violations of the Sherman Act). When referring to "antitrust" as an agent in this Article, I mean the enforcers, judges, scholars, and others who make and implement the antitrust laws.

3 Peter Sullivan, Senate Panel Launches EpiPen Investigation, THE HILL (Sept. 7, 2016), http://thehill.com/policy/healthcare/294844-senate-panel-launches-epipen-investigation; Katie Thomas, Mylan's Chief Is Chastised by Lawmakers Questioning EpiPen Pricing, N.Y. TIMES (Sept. 21, 2016), https:/www.nytimes.com/2016/09/22/business/mylan-chief-to-insist-epipenis-priced-fairly-at-house-hearing.html.

4 Andrew Pollack, Mylan Tries Again to Quell Pricing Outrage by Offering Generic EpiPen, N.Y. TIMES (Aug. 29, 2016), https://www.nytimes.com/2016/08/30/business/mylan-genericepipen.html (reporting that Mylan announced plan to introduce a generic version of its EpiPen that would sell for half the current price); Alison Kodjak, Mylan to Sell Generic EpiPen at Half the Price of Original, NPR (Dec. 16, 2016), http://www.npr.org/sections/health-shots/2016/12/ $16 / 505851637 /$ mylan-to-sell-generic-epipen-at-half-the-price-of-original (reporting that Mylan's half-price EpiPen will go on sale in December 2016).

5 Matthew Goldstein, Congress Calls Martin Shkreli to Testify on Rapid Rises in Drug Pricing, N.Y. TimES (Jan. 20, 2016), https://www.nytimes.com/2016/01/21/business/dealbook/ congress-subpoenas-martin-shkreli-over-drug-prices.html.

6 Robert Pear, Senate Aims to Stop Firms from 'Buying up Drugs and Jacking up Prices', 
Antitrust was unable to respond because of its longstanding aversion to condemning high prices unless the seller has taken some objectionable action to prevent competitors from driving prices down on their own. ${ }^{7}$ No such exclusionary conduct has been identified in the EpiPen case. To this day, the failure of competition in the EpiPen market remains a mystery; the market had generic competitors, but they did not take advantage of Mylan's high prices to meet the demand for an alternative until 2017, after the public outcry. ${ }^{8}$ That is little consolation to consumers, who paid prices far in excess of the probable unit cost of the devices of about ten dollars, inclusive of research and development costs. 9 Antitrust was relegated to pursuing Mylan in a corner of the market devoted to the sale of EpiPens to schools, because only in that narrow area was there any suggestion that Mylan had taken steps to undermine competition: namely, that the company had made schools promise not to buy from competitors. 10

N.Y. TIMES (Dec. 21, 2016), https://www.nytimes.com/2016/12/21/us/politics/prescriptiondrug-prices.html; Katie Thomas, Trump Vows to Ease Rules for Drug Makers, but Again Zeros in on Prices, N.Y. Times (Jan. 31, 2017), https://www.nytimes.com/2017/01/31/health/trumpvows-to-ease-rules-for-drug-makers-but-prices-remain-a-focus.html.

7 Verizon Commc'ns Inc. v. Law Offices of Curtis V. Trinko, L.L.P., 540 U.S. 398, 407 (2004) ("The mere possession of monopoly power, and the concomitant charging of monopoly prices, is not only not unlawful; it is an important element of the free-market system. The opportunity to charge monopoly prices-at least for a short period-is what attracts 'business acumen' in the first place; it induces risk taking that produces innovation and economic growth. To safeguard the incentive to innovate, the possession of monopoly power will not be found unlawful unless it is accompanied by an element of anticompetitive conduct.").

8 Katie Thomas, Why the Lone EpiPen Competitor Hasn't Taken Off, N.Y. TIMES (Nov. 1, 2016), https://www.nytimes.com/2016/11/02/business/also-ran-to-epipen-reaches-for-aclosing-window-of-opportunity.html (observing that the story of one EpiPen competitor that has failed to take advantage of Mylan's high prices to increase market share is one of "blunders and missed chances"); Ezekiel Emanuel, Don't Only Blame Mylan for \$600 EpiPens, FORTUNE INSIDERS (Sept. 8, 2016), https://insiders.fortune.com/dont-only-blame-mylan-for-600-epipens6ad0065373e0 (observing that two other competitors failed because one was forced to recall its product and the FDA delayed approval of the other due to "deficiencies"); Sy Mukherjee, Mylan's EpiPen Is Bleeding Market Share to Its Rivals, ForTUNE, (Mar. 6, 2016), http:// fortune.com/2017/03/06/mylan-epipen-competitors-surge (showing that Mylan's EpiPen market share started to decline only in early 2017 due to competition).

9 The production costs of an EpiPen, exclusive of research and development, appear to be around ten dollars. Tracy Seipel, EpiPen Outrage: Silicon Valley Engineers Figure Real Cost to Make Lifesaving Auto-injector Two-Pack-About \$8, MERCURY NEWs (Oct. 4, 2016), http:// www.mercurynews.com/2016/10/01/epipen-outrage-silicon-valley-engineers-figure-true-costto-make-lifesaving-auto-injector-about-10. Research and development costs were already recouped before Merck sold the drug to Mylan in 2007. Aaron E. Carroll, The EpiPen, a Case Study in Health System Dysfunction, N.Y. Times (Aug. 23, 2016), https://www.nytimes.com/ 2016/08/24/upshot/the-epipen-a-case-study-in-health-care-system-dysfunction.html (reporting that the EpiPen was developed in the 1970s); Cynthia Koons \& Robert Langreth, How Marketing Turned the EpiPen into a Billion-Dollar Business, BLOOMBERG BUSINESSWEEK (Sept. 23, 2015), https://www.bloomberg.com/news/articles/2015-09-23/how-marketing-turned-theepipen-into-a-billion-dollar-business (describing purchase of EpiPen from Merck). It may be no coincidence that the price CVS charged for its generic EpiPen in early 2017 was precisely ten dollars, after discounts. Mukherjee, supra note 8.

10 See Press Release, Senator Richard Blumenthal, Blumenthal \& Klobuchar Call for 
This Article makes the case that antitrust should use the same strategy of shaming price gougers that other parts of government now employ, by imposing a duty on businesses to charge low prices, understood to mean prices no higher than economic cost, enforceable by nominal damages only. Shaming is best pursued through the antitrust laws because those laws are backed by the expertise of two enforcement agencies dedicated to protecting consumers from high prices, not to mention a nation full of potential private antitrust plaintiffs. ${ }^{11}$ Accordingly, antitrust should be able to identify, and arouse public ire toward, instances of high pricing that, for whatever reason, would otherwise fail to come to the attention of the general public.

There are likely to be many such instances, because there is reason to think that unnecessarily high pricing is pervasive in the economy today, and certainly not limited to drug markets. Corporate profits have been at record highs at the same time that corporate investment has been at record lows, suggesting that prices across the economy are higher than necessary to cover costs. ${ }^{12}$ Industrial concentration has also grown since the 1990s, giving firms more power to charge excessive

Immediate Federal Investigation into Possible Antitrust Violations by EpiPen Manufacturer (Sept. 6, 2016), https://www.blumenthal.senate.gov/newsroom/press/release/blumenthal-andklobuchar-call-for-immediate-federal-investigation-into-possible-antitrust-violations-byepipen-manufactrurer; Press Release, New York State Office of the Attorney General, A.G. Schneiderman Launches Antitrust Investigation Into Mylan Pharmaceuticals Inc., Maker Of Epipen (Sept. 6, 2016), https://ag.ny.gov/press-release/ag-schneiderman-launches-antitrustinvestigation-mylan-pharmaceuticals-inc-maker. The Federal Trade Commission (FTC) also opened an investigation into whether Mylan used product hopping and other methods of gaming the patent system to shield EpiPen from competition, but has brought no case. David McLaughlin, Sara Forden \& Jared S. Hopkins, Mylan Faces U.S. Antitrust Investigation on EpiPen, BLOOMBERG (Jan. 31, 2017), https://www.bloomberg.com/news/articles/2017-01-30/ mylan-faces-u-s-antitrust-investigation-on-epipen-practices. A state antitrust authority also opened an investigation into whether Turing excluded generic competitors. See Andrew Pollack, New York Attorney General Examining Whether Turing Restricted Drug Access, N.Y. TiMES (Oct. 12, 2015), https://www.nytimes.com/2015/10/13/business/new-york-attorneygeneral-examining-if-turing-restricted-drug-access.html.

In the European Union, which prohibits excessive pricing, the antitrust response to price gouging in pharmaceuticals has been vigorous. Treaty on the Functioning of the European Union, Art. 102 (prohibiting excessive pricing). Both the United Kingdom and Italy have imposed fines on drug companies in response to large price increases. Press Release, Competition and Markets Authority of the United Kingdom, CMA Fines Pfizer and Flynn $£ 90$ Million for Drug Price Hike to NHS (Dec. 7, 2016), https://www.gov.uk/government/news/ cma-fines-pfizer-and-flynn-90-million-for-drug-price-hike-to-nhs; Sasha Planting, Aspen Fined $€ 5 m$ for Market Abuse, MSN (Oct. 18, 2016), https://www.msn.com/en-za/news/other/aspenfined-\%E2\%82\%AC5m-for-market-abuse/ar-AAj65xM.

11 See Andrew I. Gavil et al., Antitrust Law in Perspective: Cases, Concepts, ANd Problems in Competition Policy 1025-26 (2d ed. 2008) (describing enforcement of the antitrust laws by the FTC, Department of Justice Antitrust Division, and private plaintiffs).

12 See Einer Elhauge, Horizontal Shareholding, 129 HARV. L. REV. 1267, 1281-83 (2016) ("Instead of spending to expand output, S\&P 500 companies have retained between $\$ 3.5$ trillion and $\$ 5$ trillion in cash and spent other profits on stock buybacks, dividend payments, and high executive compensation."). 
prices. ${ }^{13}$ Probably the most dramatic instance of non-drug excessive pricing today is Apple. It is hard to view the $\$ 270$ billion of cash that Apple currently has in its bank accounts as anything other than evidence that Apple charges prices for its iPhones and other devices that are in excess of the minimum amount, inclusive of profits for investors, that Apple needs to stay in business. ${ }^{14}$

A duty to charge low prices would be fully in line with the goal of maximizing consumer welfare in the economic sense that antitrust first embraced in the 1970s under the influence of the Chicago School.15 The duties antitrust currently imposes on firms are a throwback to the days when antitrust had the very different goal of promoting competition, rather than consumer welfare. ${ }^{16}$ Operating as if that earlier goal remained on the books, antitrust today continues to impose liability only when a firm engages in some act that antitrust recognizes as anticompetitive, such as collusion with other firms, or the unilateral exclusion of competitors from the market other than by the fielding of a superior product. ${ }^{17}$ Often, however, a firm's power to charge a high price is not due to such anticompetitive behavior. A firm may be lucky enough to have incompetent competitors, as seems to be true for Mylan in the EpiPen market, or, as in the case of Apple, a firm may have used brand loyalty and a high-quality product to induce consumers to accept

13 See Too Much of a Good Thing, ECONOMIST (Mar. 26, 2016), http://www.economist.com/ news/briefing/21695385-profits-are-too-high-america-needs-giant-dose-competition-toomuch-good-thing (observing that of the "900-odd sectors covered by America's five-yearly economic census," it turns out that "[t]wo-thirds . . became more concentrated between 1997 and 2012. The weighted average share of the top four firms in each sector has risen from $26 \%$ to $32 \% . ")$.

14 Apple Inc., Annual Report (Form 10-K) 21 (Sept. 30, 2017) (reporting that Apple had $\$ 268,895,000,000$ in cash on September 30,2017 and showing that it has had at least $\$ 140,000,000,000$ in cash on its books since 2013).

15 See Herbert Hovenkamp, Federal antitrust Policy: The Law of Competition AND ITS PRACTICE 77-78 (4th ed. 2011) ("One might characterize the [change in antitrust during the 1970s and 1980s] by saying that during the 1970's and 1980's the courts and perhaps the Reagan Era antitrust division first recognized economic efficiency as the exclusive goal of antitrust policy.").

16 See N. Pac. Ry. Co. v. United States, 356 U.S. 1, 4 (1958) ("The Sherman Act was designed to be a comprehensive charter of economic liberty aimed at preserving free and unfettered competition as the rule of trade. It rests on the premise that the unrestrained interaction of competitive forces will yield the best allocation of our economic resources, the lowest prices, the highest quality and the greatest material progress, while at the same time providing an environment conducive to the preservation of our democratic political and social institutions. But even were that premise open to question, the policy unequivocally laid down by the Act is competition.").

17 See United States v. Aluminum Co. of Am., 148 F.2d 416, 430 (2d Cir. 1945) ("A single producer may be the survivor out of a group of active competitors, merely by virtue of his superior skill, foresight and industry. In such cases a strong argument can be made that, although, the result may expose the public to the evils of monopoly, the Act does not mean to condemn the resultant of those very forces which it is its prime object to foster: finis opus coronat."). 
high prices. ${ }^{18}$

Consumers are still harmed in these cases because all prices in excess of those necessary to keep firms in business reduce consumer welfare, even when those prices are not buttressed by collusive or exclusionary behavior recognized by antitrust as anticompetitive. ${ }^{19}$ Businesses must generate profit in the accounting sense to survive. But there is always such a thing as too much profit. ${ }^{20}$ When a firm earns more profit than the minimum its investors need to be willing to undertake the project, the firm earns more profit than it needs to function. The excess represents a redistribution of wealth from consumers to the firm, which is to say, harm to consumers. No one thinks Steve Jobs and his investors would have walked away from the iPhone if they had thought Apple would not be able to generate those $\$ 270$ billion in cash, but only, say, $\$ 100$ billion, which is why a large part of the $\$ 270$ billion in cash on Apple's books likely represents excessive profits and harm to consumers.

Antitrust's failure to prohibit excessive profits represents a failure to advance its new goal of consumer welfare maximization. There is, in other words, a gap between antitrust's current means of prohibiting collusion and exclusion, but not high prices, and antitrust's end of promoting consumer welfare. ${ }^{21} \mathrm{~A}$ duty to charge low prices would close that gap, at least to the extent that shame proves a useful sanction. There is some reason to think that shame will indeed prove useful. Congress has used shame to reduce prices in the past.22 Shame has also been shown to have an effect on behavior in other areas of law. ${ }^{23}$ Moreover, as

18 See Thomas, supra note 8; John Laugesen \& Yufei Yuan, What Factors Contributed to the Success of Apple's IPhone?, 2010 NINTH INT'L CONF. ON MOBILE BUS. / 2010 NINTH GLOBAL MOBILITY ROUNDTABLE (2010) (attributing the success of the iPhone to five factors, including user preference, culture, and innovative technology).

19 See HovenKamP, supra note 15, at 627 (observing that perfect price discrimination, which involves tailoring, and therefore increasing, prices to consumers, always reduces consumers' welfare).

20 See Ramsi A. Woodcock, Inconsistency in Antitrust, 68 U. MIAMI L. REV. 105, 126-36 (2013) [hereinafter Woodcock, Inconsistency in Antitrust] (providing a graphical model explaining this point).

21 For discussions of collusion and exclusion, see GAVIL ET AL., supra note 11, at 45-49; Richard A. Posner, ANTITRUST LAW 40-41 (2d ed. 2001).

22 Sara Fisher Ellison \& Catherine Wolfram, Coordinating on Lower Prices: Pharmaceutical Pricing Under Political Pressure, 37 RAND J. ECON. 324, 337 (2006) (concluding from an analysis of pricing data that politically vulnerable firms reduced wholesale drug prices in the early 1990s during debates over healthcare reform); Austin Frakt, Even Talking About Reducing Drug Prices Can Reduce Drug Prices, N.Y. Times (Jan. 18, 2016), https://www.nytimes.com/ 2016/01/19/upshot/even-talking-about-reducing-drug-prices-can-reduce-drug-prices.html (listings instances in which tough talk by Congress drove drug price reductions). Some antitrust scholars argue that the threat of antitrust litigation affects firm behavior as well. See GAVIL ET AL., supra note 11, at 1111-12 ("The mere filing and prosecution of an antitrust case sometimes alters the defendant's conduct.").

23 See Matthew Krain, J'accuse! Does Naming and Shaming Perpetrators Reduce the Severity of Genocides or Politicides?, 56 INT'L STUD. Q. 574, 585 (2012) (concluding that shaming lessens 
Ian Ayres has pointed out, the greatest total (consumer plus producer) welfare gains come from the first reductions in prices below monopoly levels. ${ }^{24}$ Thus those who believe that antitrust should care about total welfare, in addition to consumer welfare, will be cheered to know that the lion's share of any total welfare losses due to high pricing could be eliminated by only a modest shaming effect on prices.

The proposed pricing duty would be enforced only by nominal damages, thereby deflecting one of the great objections of U.S. courts to interpreting the antitrust laws to prohibit high prices: that courts have neither the expertise nor the resources to set better prices. ${ }^{25}$ Courts would need to decide whether prices are too high in order to enforce a low pricing duty, but judging whether prices are too high is not the same thing as deciding the magnitude of the excess, let alone ordering firms to charge the correct lower price. The nominal damages remedy allows courts to substitute a judgment in the amount of one dollar for cumbersome price setting in every case.

The much more modest task of deciding whether prices are too high is a normal judicial function. Courts regularly judge whether prices are too high, both in antitrust cases and in other areas of law. 26 They judge prices when they award overcharge damages in price fixing cases, for example, and when they review contracts for unconscionability. ${ }^{27}$

the severity of international human rights violations).

24 Ian Ayres, Pushing the Envelope: Antitrust Implications of the Envelope Theorem, 17 Miss. C. L. REV. 21, 23-24 (1996). Ayres argues that government can exploit this phenomenon in a number of ways, including by "target firms that seem to be charging too much... even if it created only a small probability of ultimate liability." Id. at 24 .

25 See Verizon Commc'ns Inc. v. Law Offices of Curtis V. Trinko, L.L.P., 540 U.S. 398, 408 (2004) ("Enforced sharing also requires antitrust courts to act as central planners, identifying the proper price, quantity, and other terms of dealing-a role for which they are ill-suited."); Chicago Prof. Sports Ltd. v. Nat. Basketball Ass'n, 95 F.3d 593, 597 (7th Cir. 1996) ("[T]he antitrust laws do not deputize district judges as one-man regulatory agencies."); IIIA HERBERT J. HOVENKAMP, ANTITRUST LAW, 6 (4th ed. 2015) ("IJ]udicial decrees requiring the monopolist to charge the competitive price encounter all the numerous difficulties that have plagued agency price regulation of public utilities generally, but in this case are compounded by the fact that judicial tribunals lack both the expertise and the narrow jurisdictional focus necessary to make such regulatory schemes work at all.”).

26 See infra Section III.B.

27 See Chattanooga Foundry \& Pipe Works v. Atlanta, 203 U.S. 390, 396, 399 (1906) (affirming an antitrust judgment calculated as "the difference between the price paid and the market or fair price that the [plaintiff] would have had to pay under natural conditions had the combination been out of the way"); Perdue v. Crocker Nat'l Bank, 702 P.2d 503, 926-27 (Cal. .1985) (stating that "the price term, like any other term in a contract, may be unconscionable.... The courts look to the basis and justification for the price, including the price actually being paid by ... other similarly situated consumers in a similar transaction" (citations omitted) (quotation marks omitted)); U.C.C. $\$ 2-302 \mathrm{cmt}$. 1 (AM. LAW INST. \& UNIF. LAW COMM'N 2014) ("This section is intended to allow the court to pass directly on the unconscionability of the contract or particular clause therein and to make a conclusion of law as to its unconscionability. The basic test is whether, in the light of the general commercial background and the commercial needs of the particular trade or case, the clauses involved are so one-sided as to be unconscionable under the circumstances existing at the time of the 
Courts prefer to be wary of following up on a judgment that price is too high by deciding what the proper price should be, preferring to leave it to Congress instead to create expert administrative agencies to carry out that task. ${ }^{28}$ But courts in fact regularly go so far as to set prices, often without seeming to realize that they are doing so, when they engage in as common a judicial activity as the determination of compensatory damages, which put a price on bad conduct. Courts also occasionally engage in more conscious price setting when they require a firm to deal with rivals in antitrust cases. ${ }^{29}$ Regardless, the proposed duty to charge low prices would spare the courts the need to decide on the right price. Under the proposed duty, the shamed business alone would choose whether and by how much to cut.

The two other major global antitrust authorities, the European Union and China, both prohibit excessive pricing. ${ }^{30}$ But calls for U.S. antitrust to prohibit high prices have been infrequent. ${ }^{31}$ Harry First has recently argued that the Federal Trade Commission (FTC) should use its extraordinary powers under Section 5 of the FTC Act to challenge high prices, at least for drugs, and presumably to order lower prices by way of remedy. 32 The duty to charge low prices proposed in this Article would make high pricing a violation not only of Section 5, the scope of which is unclear, but of core antitrust law: Section 2 of the Sherman Act. 33

Another approach to eliminating high prices would be to remove

making of the contract.").

28 See infra Section III.A.

29 Aspen Highlands Skiing Corp. v. Aspen Skiing Co., 738 F.2d 1509, 1513, 1527-28 (10th Cir. 1984) (affirming a judgment that included an injunction requiring the defendant to supply ski tickets to the plaintiff); Microsoft Corp. v. Motorola, Inc., 795 F.3d 1024, 1056-57 (9th Cir. 2015) (affirming judicial determination of the license fee to be charged for intellectual property that the licensor was bound by contract to license on reasonable and non-discriminatory terms).

30 Treaty on the Functioning of the European Union art. 102(a), Oct. 26, 2014, O.J. (C 326) (prohibiting "[a]ny abuse by one or more undertakings of a dominant position" and defining abuse to include "directly or indirectly imposing unfair purchase ... prices"); Anti-Monopoly Law of the People's Republic of China art. 17(1) (People's Republic of China) ("Undertakings holding dominant market positions are prohibited from doing the following by abusing their dominant market positions:... selling commodities at unfairly high prices or buying commodities at unfairly low prices.").

31 Objections to enforcement of the European Union rule, like objections to adoption of a rule against high prices in the United States, center on administrability. See Liyang Hou, Excessive Prices Within EU Competition Law, 7 EUR. COMPETITION J. 47, 47-51 (2011) (describing the debate and observing that European enforcement authorities have ruled that prices were excessive in only two cases).

3215 U.S.C. $\$ 45$ (2012); Harry First, Unfair Drug Prices and Section 5, 3-7 (NYU Ctr. for Law, Econ. \& Org., Working Paper No. 16-03, 2015); William E. Kovacic \& Marc Winerman, Competition Policy and the Application of Section 5 of the Federal Trade Commission Act, 76 ANTITRUST L.J. 929, 929 (2010) ("As interpreted by the U.S. courts, Section 5 enables the FTC to proscribe behavior beyond conduct prohibited by the other federal antitrust statutes ....").

3315 U.S.C. $\$ 2$. 
anticompetitive conduct as a requirement for antitrust liability, but not to substitute the charging of high prices as a new requirement. Under this alternative approach, a firm with monopoly power could be broken up by the courts regardless whether the firm in fact either charged high prices or engaged in collusive or exclusionary conduct. ${ }^{34}$ This no-fault deconcentration approach has not had substantial support since the early 1970s, however. ${ }^{35}$ Unlike no-fault deconcentration, the duty to charge low prices proposed in this Article would not condemn size in itself, so long as the big firm charges low prices. Although this Article should not be understood to reject other alternatives, one advantage of the approach proposed in this Article is that it would not involve the challenges of breaking up a big firm that could accompany the no-fault deconcentration approach.

Part I of the Article considers the odd fact that antitrust, and the law-and-economics movement generally, have never tried the most direct strategy available for maximizing either consumer or total welfare: asking businesses to do the right thing by choosing a fair price, rather than a profit-maximizing one. 36 If the law-and-economics movement is serious about maximizing either consumer or total welfare, then imposing an effectively voluntary duty on businesses to choose welfare-maximizing prices, as a duty to charge low prices would do for consumer welfare, seems like the first step to take.

Part II discusses the gap between antitrust ends and means that opened up when antitrust replaced its old goal of promoting competition with the goal of maximizing consumer welfare in the economic sense. 37 Bringing means into harmony with ends is the Article's primary legal argument for embracing a duty to charge low prices. Part III reviews judicial practice in relation to prices, showing that if courts are not completely comfortable with price-setting, they are comfortable with passing judgment on whether prices are too high or too low. 38

Part IV describes in detail the proposed duty to charge low prices, understood to mean prices equal to costs inclusive of the cost of rewarding investors. Part IV argues that the duty is likely to impose a

34 See CARl Kaysen \& Donald F. TuRner, Antitrust Policy: An ECONOMiC AND Legal ANALYSIS (1959) (arguing for separate legislation providing for deconcentration of U.S. industry, regardless of fault); Oliver E. Williamson, Dominant Firms and the Monopoly Problem: Market Failure Considerations, 85 HARV. L. REV. 1512, 1513, 1530-31 (1972) (arguing that persistent monopoly is possible, even in the absence of collusion or exclusion, and that Section 2 of the Sherman Act should be read to prohibit dominance in itself, regardless of conduct); Ramsi A. Woodcock, Big Data, Price Discrimination, and Antitrust, 68 HASTINGS L.J. 1371, 1404 (2017).

35 See infra note 61.

36 See infra Part I.

37 See infra Part II.

38 See infra Part III. 
minimal burden on the courts because the nominal damages remedy, combined with the related absence of attorney fee shifting, will discourage plaintiffs from bringing all but the most important cases. ${ }^{39}$ Part IV also discusses the argument that even if the rule has only a modest effect on prices, it can have a large effect on total welfare. 40 Finally, Part IV shows that because judicial determinations regarding whether prices are too high are necessarily speculative, nominal damages, as well as abrogation of the normal antitrust attorney fee shifting rules, would be appropriate under prevailing remedies doctrine. ${ }^{41}$

\section{A Low PRICING DUty as a LAW-AND-ECONOMICS ProjeCt}

Economists have shown that if people behave rationally in the sense that they maximize their private welfare, which is to say, their profit, and all decisions regarding the allocation of resources in society are made through perfectly competitive markets, the aggregate wealth of society, otherwise known to economists as total or social welfare, will be maximized. ${ }^{42}$ This is the promise of the invisible hand. ${ }^{43}$ While scholars long ago recognized the assumptions of rationality and perfect competition to be unrealistic, and the invisible hand therefore ineffective, these assumptions continue to exert a strong influence on the law-and-economics movement, if only as ideals. ${ }^{44}$ The invisible hand has been treated as the only possible route to maximization of social welfare, and the failure of the assumptions underlying it treated as

39 See infra Part IV

40 See infra Section IV.A.2.

41 See infra Section IV.C.

42 See ANdreu Mas-Colell et Al., Microeconomic Theory 547-49 (1995) (defining a Walrasian equilibrium as one in which consumers and firms trade to maximize their welfare and markets are competitive, and giving conditions under which such an equilibrium is welfare maximizing in the Pareto sense).

43 See id. at 549 (describing the Pareto efficiency of Walrasian equilibrium as "a formal and very general confirmation of Adam Smith's asserted 'invisible hand' property of the market").

44 For a defense of the rationality assumption that reviews much of the mid-twentiethcentury literature questioning it, see Jack Hirshleifer, The Expanding Domain of Economics, 75 AM. ECON. REV. 53 (1985). The study of monopoly appears to be as old as classical economics, and in the context of the ownership of land might even be reasonably described as the original preoccupation of economics as an intellectual discipline. See DAVID RICARDO, PRINCIPLES OF POLITICAL ECONOMY AND TAXATION 47-48 (1817) (setting forth the Ricardian model of rent). For a discussion of how economists in the 1930s came to understand competitive markets as the exception, see Herbert Hovenkamp, United States Competition Policy in Crisis: 1890-1955, 94 MiNN. L. REV. 311, 317-19 (2009) (discussing, in particular, the work of Joan Robinson); see also John M. Clark, Toward a Concept of Workable Competition, 30 AM. ECON. REV. 241, 241 (1940) (observing that with the arrival of theories of monopolistic competition "has come the realization that 'perfect competition' does not and cannot exist and has presumably never existed"). 
something to be reversed, rather than as a signal that other routes toward maximization of social welfare apart from the invisible hand should be tried. ${ }^{45}$ In particular, the law-and-economics movement has responded to the absence of perfect competition not by seeking alternative ways to organize production, but by trying, through antitrust, to restructure markets to render competition more perfect where possible. 46

This singular focus on the elements of the invisible hand has rendered law-and-economics blind to the fact that rationality and competition are not the only possible means toward the maximization of social welfare. ${ }^{47}$ Indeed, this focus has prevented law-and-economics from appreciating the good fortune that both pillars of the invisible

45 See DAvid M. KReps, A Course In Microeconomic Theory 5 (1990) (observing that even though data suggests that agents are not rational, "we can still gain insight into questions of interest by studying models where we assume away these violations"). Game theory, which became a major force in industrial organization economics in the 1980s, is the study of markets in which there are not enough buyers and sellers for a competitive outcome to arise. Franklin M. Fisher, Games Economists Play: A Noncooperative View, 20 RAND J. ECON. 113, 113 (1989) (identifying the 1980s as the decade in which game theory became ascendant in industrial organization); MAS-COLELL ET AL., supra note 42, at 217-18 ("In settings of . . . perfect competition, the nature of strategic interaction is minimal enough that our analysis need not make any formal use of game theory. In ... the analysis of oligopolistic markets, the central role of strategic interaction makes game theory indispensable ...." (internal parentheticals omitted)). Hovenkamp describes game theory's influence in antitrust economics as "negative rather than positive-it serves to undermine our confidence that the market is always as efficient as traditional Chicago economics implied, but we really don't know very much about the nature or extent of the deviations." HovenKAMP, supra note 15, at 78.

46 This is perhaps most obvious in the case of conservative commentators. See ROBERT H. Bork, The ANTitrust Paradox: A Policy AT WAR With ItSelf 91 (1993) (arguing that the purpose of antitrust is "to improve allocative efficiency without impairing productive efficiency," meaning that it is to promote competition (allocative efficiency) only when monopoly is not efficient (there is no productive efficiency to be had from large firms)); John S. McGee, Why Not "Deregulation" for Antitrust?, 46 ANTITRUST L.J. 777, 777, 785 (1977) (arguing both for deregulation and against antitrust enforcement against large firms). Law-andeconomics does sometimes recognize a limited place for the alternative of price regulation, but law-and-economics seems content to allow many markets that antirust is unable to repair to go without price regulation or any other fix, if only by withdrawing antitrust from the field, and leaving it to a fickle legislature to impose price regulation ad hoc. This is expressed in the notion that rate regulation is mainly appropriate only for natural monopoly, meaning monopoly due to economies of scale, but not appropriate for monopoly due to luck or access to some rare input, such as management talent. Compare W. KIP VISCUSI ET AL., ECONOMICS OF REGULATION AND ANTITRUST 376 (4th ed. 2005) ("There is a basis for [rate regulation and other forms of government intervention] in that under certain conditions, unrestrained competition does not work very well. Two common circumstances are that an industry is a natural monopoly or that it is plagued by externalities."), with Williamson, supra note 34 , at 1513 ("As the law is currently interpreted, dominance does not constitute a Section 2 violation if the structure of the industry is attributable to 'a superior product, business acumen, or historic accident."'), and HOVENKAMP, supra note 15, at 5-7 (arguing that price regulation by antitrust courts is inappropriate, regardless whether it is necessary to protect consumer welfare).

47 See, e.g., Jonathan B. Baker, Competition Policy as a Political Bargain, 73 ANTITRUST L.J. $483,486,490$ (2006) (characterizing antitrust as a compromise between the alternatives of government-sponsored monopoly and rate regulation). 
hand have failed, rather than just that of perfect competition. If firms were rational, then the absence of perfect competition would condemn society to monopoly pricing. Rational firms maximize profit by charging above-cost prices, and this leads to at-cost prices and maximization of social welfare only when perfect competition prevents firms from actually succeeding at charging the high prices they seek to charge. 48 Without the discipline of competition, profit maximizing behavior results in above-cost prices, causing some consumers who would buy at at-cost prices, and therefore should buy if social welfare is to be maximized, to be priced out of the market. ${ }^{49}$ It follows that to maximize social welfare in a world of imperfect competition, firms ought not strive to charge above-cost prices, and therefore ought not be rational.50 So it is a matter of good fortune that the assumption of rationality fails along with the assumption of perfect competition.

For a law-and-economics movement that has been liberated from its obsession with rationality and competition, the obvious place to start in maximizing social welfare is to impose a duty on all firms to do just that: maximize social welfare. That is, the obvious place to start in a world of irrationality and imperfect competition is just to compel firms to behave irrationally in the right way. The thesis of this Article is that the first step toward doing that is to ask firms, politely, to comply with such a duty. Ask people to do the right thing; worry about other approaches only if they do not. Instead of treating human nature as fixed, law-and-economics must start to treat human nature as capable of being influenced: a policy variable. The most basic and as yet untried way to do that is to talk to human beings. Indeed, firms themselves learned that lesson long ago; firms ask consumers to put aside their selfinterest and become fat on sugar water, or dead on cigarettes, all the time. ${ }^{51}$ Firms call that marketing. ${ }^{52}$ Now it is time for law-and-

48 See KREPS, supra note 45, at 5 ("The actions taken by any individual depend on the opportunities that are presented to the individual. Those opportunities, in turn, often depend upon the collective actions of others. And the consequences for an individual of that individual's actions usually depend on what others have chosen to do.").

49 See sources cited supra note 42.

50 Imperfect competition gives agents control over the prices that they set; if the agents are rational, they will set prices that maximize their own welfare, and not necessarily the welfare of society. See Robert Cooter \& Melvin Aron Eisenberg, Damages for Breach of Contract, 73 CALIF. L. REV. 1432, 1451 (1985) (defining an imperfectly competitive market as one in which "some participants in a market have power over the prices and terms of contracts").

51 See Caroline Schooler et al., Seventh Graders' Self-Reported Exposure to Cigarette Marketing and Its Relationship to Their Smoking Behavior, 86 AM. J. PUB. HEALTH 1216, 1216 (1996) (reporting billions of dollars in tobacco marketing expenditures and a statistically significant effect on tobacco consumption by youth); INST. MED. NAT'L ACADS., FOOD MARKETING TO CHILDREN AND YOUTH: THREAT OR OPPORTUNITY? 379-80 (2006) (concluding based on a review of the literature that there is strong evidence that television advertising is associated with excessive weight in certain age groups of children and that television advertising influences food consumption choices in children). See generally Ramsi A. 
economics to try.

Asking firms to maximize social welfare through their pricing decisions amounts to asking them to choose a price that is just high enough to cover their unit costs of production, including just enough profit to make them willing to remain in the market selling their wares, but not a penny more. Such at-cost pricing maximizes consumer welfare because it ensures that firms charge no more than necessary to make them willing to serve consumers. Cost-based pricing also maximizes social welfare because it (1) ensures that all those who can afford to pay the unit cost of production of the good have access to it, and (2) creates no unnecessary profits for the seller that might encourage others to waste money trying to acquire those profits by undermining competition, but (3) does not dissuade the seller from selling. ${ }^{53}$ Asking firms to engage in at-cost pricing amounts to asking firms to behave irrationally because it demands that firms voluntarily forego any profits beyond those necessary to induce them to remain in the market. But it is reasonable irrationality. By definition, at-cost pricing allows a firm any profits that the firm needs to be ready, willing, and able to remain in the market. The firm breaks even, inclusive of all opportunity costs, under this rule.

One of the principal reservations of law-and-economics regarding the viability of perfect competition is the possibility that competition might drive prices so low that firms end up lacking the profits they need to afford the kind of large investments in research and development that

Woodcock, The Obsolescence of Advertising in the Information Age, 127 YALE L.J. (forthcoming 2018) (treating advertising as manipulation). For the importance of talking to those who appear unable to listen, see TALK TO HER (El Deseo S.A. 2002) (fictional film portraying conversations with the comatose).

52 See, e.g., Stephen J. Hoch \& George F. Loewenstein, Time-Inconsistent Preferences and Consumer Self-Control, 17 J. CONSUMER RES. 492, 496-98 (1991) (listing ways in which marketers induce consumers to abandon long-term preferences, including by placing a product close to a consumer).

53 (1) and (3) guarantee productive efficiency: that what people want, in the sense of being willing to pay for, is produced. If price discrimination is possible, they also guarantee allocative efficiency. (2) ensures no Posnerian monopoly inefficiency. See Richard A. Posner, The Social Costs of Monopoly and Regulation, 83 J. POL. ECON. 807, 809-12 (1975) (arguing that firms will expend resources to obtain and defend monopoly, and that such expenditures are wasteful). The arguments in the paragraph accompanying this footnote are strictly true only in the many important cases in which a firm's fixed costs, such as the costs of research and development, exceed producer surplus at a price that equilibrates demand and marginal cost, because only in this context is it always true that price increases above cost reduce consumer welfare. If firms can cover their costs at a price below that which equilibrates demand and marginal cost, then increasing price above cost increases social welfare. When fixed costs do not exceed producer surplus at a price that equilibrates demand and marginal cost, social and consumer welfare maxima may not be associated with the same price. Social welfare will be maximized at the price that equilibrates demand and marginal cost, whereas consumer welfare may be maximized at a lower price. But this divergence notwithstanding, the basic lesson that law-andeconomics cannot achieve its goal, whether of social or consumer welfare maximization, without asking agents to behave irrationally, is still valid. 
drive economic growth. ${ }^{54}$ At-cost pricing creates no such risk. Both expenditures on research and development and the financial reward that investors need to be willing to fund those expenditures count as costs in the economic sense. ${ }^{55} \mathrm{~A}$ seller is entitled to recover both through at-cost pricing. At-cost pricing requires only that the price charged be no higher than necessary to cover those and all other costs. At-cost pricing deprives the seller only of more than the seller needs. In imploring a seller to price at cost, a low pricing duty would implore the seller to renounce that excess voluntarily, for the good of the public.

Herbert Hovenkamp suggests that asking a firm to price competitively, which is to say, at cost, would go against the firm's "natural instincts" and subject the firm to "uncertainty." 56 The assumption that the natural instincts of the firm are to maximize profit, which is what a rational actor would do, is a relic of a bygone age of economics and merits no further discussion. ${ }^{57}$ But the argument that atcost pricing subjects a monopolist to uncertainty deserves a closer look.

Hovenkamp supports this argument by contrasting the power of a firm in a competitive market to charge a price equal to cost with the power of a monopolist to charge that price. ${ }^{58}$ According to Hovenkamp, the firm in the competitive market finds it relatively easy to charge a price equal to cost, because competition drives the market price down to cost. To choose the at-cost price, the firm in the competitive market need only determine the price charged by competitors. By contrast, according to Hovenkamp, the monopolist cannot rely on the prices charged by others to determine the at-cost price, because there are no competitors. The monopolist can identify the at-cost price only by determining consumer demand at different levels of output. If demand is very large at a low price, then it may be worthwhile for the firm to produce at a large volume and sell at a low price, albeit one still equal to cost. If instead consumers place a low value on the product, then it may be worthwhile for the firm to produce fewer units and charge a high price, albeit one no higher than necessary to cover the firm's fixed costs

54 See Robert M. Solow, Technical Change and the Aggregate Production Function, 39 REV. ECON. \& STAT. 312, 320 (1957) (finding that about eighty-five percent of U.S. economic growth from 1909 to 1949 was due to innovation); JOEL MOKYR, THE ENLIGHTENED ECONOMY: AN ECONOMIC HISTORY OF BRITAIN 1700-1850 (2009) (reviewing the causes of industrialization).

55 See Woodcock, Inconsistency in Antitrust, supra note 20, at $127 \mathrm{n} .56$ (making this argument and distinguishing economic from accounting cost); HOVENKAMP, supra note 15, at 151 (" $[\mathrm{A}]$ firm earning zero in economic profits is nevertheless paying its investors the opportunity cost of their capital-or the same rate that they could get in an alternative competitive investment of equivalent risk."); PhILlIP AREEDA ET AL., ANTITRUST ANALYSIS: Problems, TEXT, CASES 20 (2004) ("[B]eneficiaries of imperfect competition . . receive income unnecessary to induce their production. Their capital would have been invested without the promise of such large returns.").

56 HovenKAMP, supra note 15 , at 3.

57 See supra notes 44-45.

58 See HovenKamP, supra note 15 , at 3. 
on a lower volume of sales. No firm has perfect knowledge of consumer demand, so the monopolist faces uncertainty in trying to charge a price equal to cost, uncertainty that a firm in a competitive market does not face.

Hovenkamp's mistake is to use the wrong baseline in evaluating the difficulty for the monopolist of choosing the at-cost price. In a world of imperfect markets, the choice faced by law-and-economics is between a world in which monopolies charge monopoly prices and a world in which monopolies, not firms operating in competitive markets, charge at-cost prices. ${ }^{59}$ A monopoly faces no more uncertainty determining the at-cost price than it faces in determining the profit-maximizing price because a monopoly must also have knowledge of consumer demand in order to identify the profit-maximizing price. The monopolist aiming at a profit-maximizing price that misjudges demand for the monopolist's product and consequently sets too high a price will fail to maximize profits, because so many consumers will abandon the product that lost profits on the abandoned units will exceed the extra profits generated on the units the firm is able to sell at higher prices. Similarly, the monopolist aiming at cost-based pricing that thinks consumers have a stronger appetite for the product than consumers really do, and sells at too low a price on the mistaken assumption that consumers will buy in sufficient numbers to cover costs, sets prices too low to cover costs, frustrating the goal of at-cost pricing. 60 Thus asking a monopoly to price at cost asks no more of the monopoly than what the monopoly asks of itself in striving to price monopolistically: knowledge of consumer demand.

\section{The Gap Between END ANd MEANS In CONTEMPorary ANTITRUST}

\section{A. The Gap}

For most of antitrust's existence, the law's end fit its means. The courts understood antitrust's end to be the promotion of competition and antitrust's means to be the condemnation of practices that injure competition, whether collusion between competitors or exclusionary conduct by individual firms seeking to force competitors out of the

$59 \mathrm{Id}$. at 3 n. 3 .

60 For a demonstration of this using agent-based modelling, see STEVEN ORLA KIMBROUGH, AgENTs, GAMES, AND Evolution: STRATEGIES AT WORK AND Play 187-88 (2011) ("Even if we assume that the monopolist knows its own costs precisely, it will rarely have access to an exact, twice differentiable, static demand function with which to calculate its optimal response."). 
market. 61 That changed starting in the 1970s, when the Chicago School began convincing the courts to embrace the maximization of consumer welfare as the goal of antitrust.62 Embrace of the consumer welfare standard created a gap between end and means because condemning practices that injure competition drives prices below cost in some cases, and leaves them above cost in others, both to the detriment of consumers. Thus, antitrust's means of regulating competition became unable to carry out antitrust's new end.

61 The explicit rejection of welfare as an end, in favor of competition, is striking in the caselaw before 1970 or so. See N. Pac. Ry. Co. v. United States, 356 U.S. 1, 4 (1958) ("[U]nrestrained interaction of competitive forces will yield the best allocation of our economic resources .... But even were that premise open to question, the policy unequivocally laid down by the Act is competition."); Brown Shoe Co. v. United States, 370 U.S. 294, 344 (1962) ("[W]e cannot fail to recognize Congress' desire to promote competition through the protection of viable, small, locally owned businesses. Congress appreciated that occasional higher costs and prices might result from the maintenance of fragmented industries and markets. It resolved these competing considerations in favor of decentralization. We must give effect to that decision."). Indeed, the opposition to concentration at all costs is reflected in Justice Stevens's famous complaint that in merger cases "the Government always wins." United States v. Von's Grocery Co., 384 U.S. 270, 301 (1966). In this period, antitrust still protected large firms that had not engaged in exclusionary conduct. See United States v. Aluminum Co. of Am., 148 F.2d 416, 430 (2d Cir. 1945) (stating that a firm that monopolizes through "superior skill, foresight and industry," as opposed to exclusionary conduct, does not run afoul of the antitrust laws). This was in line with the goal of promoting competition because the exemption applied only to large firms that were a feature of competition: those that had formed through the competitive process, without application of collusion or exclusion. It did not reflect a desire to promote welfare, but rather a sense that it would be unfair to punish, through breakup, those who had succeeded through genuinely competitive behavior. See id. ("The successful competitor, having been urged to compete, must not be turned upon when he wins.").

62 See Cont'l TV, Inc. v. GTE Sylvania Inc., 433 U.S. 36, 53 n.21 (1977) (“Competitive economies have social and political as well as economic advantages, but an antitrust policy divorced from market considerations would lack any objective benchmarks." (internal citation omitted)); United States v. U.S. Gypsum Co., 438 U.S. 422, 441 n.16 (1978) (using the possible "efficiency" of exchanges of price data to explain the absence of a per se rule against them); Broadcast Music, Inc. v. Columbia Broad. Sys., Inc., 441 U.S. 1, 19-20 (1979) (describing the job of a court in reviewing an agreement between competitors to determine whether it violates antitrust law as ascertaining whether the agreement would "decrease output" or "increase economic efficiency" (internal quotation marks omitted)); GAVIL ET AL., supra note 11, at 17273 (describing Broadcast Music as "herald[ing] ... greater focus on economic efficiency in antitrust analysis" and observing that "recently appointed federal judges associated with the Chicago School ... . wasted no time in reading [Broadcast Music as] an invitation to ... evaluate agreements among rivals for their tendency to promote output and productive efficiency"); Richard A. Posner, The Rule of Reason and the Economic Approach: Reflections on the Sylvania Decision, 45 U. CHI. L. REV. 1, 13 (1977) (hailing the Sylvania decision as suggesting that going forward "antitrust prohibitions must have an economic rationale and ... the aesthetic delights of smallness and the yearning to resurrect a nation of sturdy Jeffersonian yeomen will not be permitted to decide antitrust cases"). The case for welfare as the goal of antitrust may be found in Robert H. Bork, Legislative Intent and the Policy of the Sherman Act, 9 J.L. \& ECON. 7, 7 (1966) ("My conclusion, drawn from the evidence in the Congressional Record, is that Congress intended the courts to implement (that is, to take into account in the decision of cases) only that value we would today call consumer welfare. To put it another way, the policy the courts were intended to apply is the maximization of wealth or consumer want satisfaction."). 
Condemning anticompetitive conduct can drive prices below cost when the anticompetitive conduct is aimed at stopping free riding by competitors, as when a firm asserts a patent to prevent competitors from appropriating an invention without bearing the costs of research and development that went into creating the invention. ${ }^{63}$ Or where the conduct is aimed at preventing firms from sacrificing the revenues they need to cover sunk costs in order to gain market share. ${ }^{64}$ The railroads once argued, for example, that they should be permitted to collude, otherwise ruinous competition would drive prices so low that they would be unable to meet the massive costs associated with building and maintaining rail lines. 65

Condemning anticompetitive conduct can also fail to drive prices down to cost. This happens, for example, if a monopolist has the good fortune of having inept competitors, competitors which, through stupidity, sloth, or infighting of management are unable to match the quality or price of the monopolist, even though more competent competitors would be able to do so. ${ }^{66}$ In this case, the monopolist will be

63 See Kenneth W. Dam, The Economic Underpinnings of Patent Law, 23 J. LEGAL STUD. 247, 247 (1994) (arguing that the problem solved by patents "is that, if a firm could not recover the costs of invention because the resulting information were available to all, then we could expect a much lower and indeed suboptimal level of innovation. In short, the patent system prevents others from reaping where they have not sown and thereby promotes research and development [R\&D] investment in innovation"); F.M. SCHERER \& DAVID ROSS, INDUSTRIAL MARKET STRUCTURE AND ECONOMIC PERFORMANCE 622-24 (3d ed. 1990).

64 See Eliot Jones, Is Competition in Industry Ruinous, 34 Q.J. ECON. 473, 473-75 (1920) ("The main explanation of th[e] tendency toward ruinous competition is the proportionately large investment in fixed and specialized plant. The large investment in fixed plant gives rise to large fixed expenses, that is, expenses that do not vary in proportion to changes in the volume of [business]; and it thus pays a [firm] to attract additional [business] at any rate which exceeds the extra cost incurred on account of the increased business. The rate on this additional [business] need not cover its proportionate share of the fixed expenses, since these expenses will continue whether or no the added [business] be taken; it suffices if the rate is high enough to make some contribution, however slight, to the fixed expenses .... It should be abundantly clear that rates that deny stockholders adequate dividends as well as those that deny bondholders their interest on a proper indebtedness will discourage further investments..., and will result in an inferior quality of service.").

65 See United States v. Trans-Missouri Freight Ass'n, 166 U.S. 290, 330 (1897) ("When a railroad is once built, it is said, it must be kept in operation; it must transport property, when necessary in order to keep its business, at the smallest price and for the narrowest profit, or even for no profit, provided running expenses can be paid, rather than not to do the work; that railroad property cannot be altered for use for any other purpose, at least without such loss as may fairly be called destructive; that competition while, perhaps, right and proper in other business, simply leads in railroad business to financial ruin and insolvency...."); Walter Adams, The Rule of Reason: Workable Competition or Workable Monopoly, 63 YALE L.J. 348, 355-56 (1953). Antitrust has strengthened its intellectual property protections in recent years precisely in order to address the gap between ends and means in this area. See Woodcock, Inconsistency in Antitrust, supra note 20, at 116-23 (discussing the antitrust exemption for property-based exclusion). For other ways antitrust has sought to raise prices, see infra text accompanying note 68 .

66 See Williamson, supra note 34, at 1518 ("[T]he advantage of the dominant firm may be attributable to the ineptitude of actual and potential rivals."). Luck, too, fattens a firm. See id. at 
able to charge above-cost prices without having to engage in anticompetitive conduct. To argue that prices must always fall to cost once any anticompetitive conduct has been eliminated, because opportunity always attracts those capable of exploiting it, is to ignore the failure of countless civilizations to industrialize over millennia, not to mention the failure of luggage manufacturers for decades to put wheels and a retractable handle on carryon bags, notwithstanding their command over all of the same material and technological prerequisites as those manufacturers which eventually did. 67

To fill the gap between end and means, antitrust must do two things. First, in cases in which condemnation of anticompetitive conduct allows firms too little profit, antitrust must desist from condemning that conduct. Second, in cases in which condemnation of anticompetitive conduct insufficiently reduces profit, antitrust must find other means of reducing profit. Only in this way can antitrust achieve its goal of maximizing consumer welfare.

Antitrust has so far made only the first repair, but not the second, revising its traditional means when those means would reduce profit by too much, but doing nothing when those means fail to reduce profit enough. This partial response is reflected in antitrust's shift, starting in the 1970s, from per se rules to rules of reason. 68 Per se rules are outright bans of anticompetitive practices, whereas rules of reason permit courts to exempt some forms of anticompetitive conduct from liability on a case-by-case basis when courts find that competition would reduce prices and profits by too much. ${ }^{69}$ Substituting rules of reason for per se rules therefore gave courts the power to save anticompetitive practices from condemnation whenever it appeared to courts that profits might be driven below cost, and consumers therefore harmed, by competition.

The shift to rules of reason was dramatic. At the start of the 1970s,

1519 (" $[R]$ epeated application of the same stochastic mechanism that, within a relatively brief interval, [gives] rise in some industries to concentration cannot reliably be expected to undo this result in any short period of time."). For the argument that all monopoly power must be based on exclusionary conduct, and that antitrust's inability to target all high prices is therefore due to antitrust's failure entirely to prohibit all exclusionary conduct, see Woodcock, Inconsistency in Antitrust, supra note 20, at 136-54.

67 See Wheeled Suitcase and Luggage Support, U.S. Patent No. 4,995,487 (issued Aug. 8, 1989) (being the first patent on a wheeled carryon bag with retractable handle); MOKYR, supra note 54 (concluding that industrialization was brought about not by special access to resources, development of financial systems, or other structural factors, but simply by a love, of those living in the age of industrialization, for tinkering).

68 See Ramsi A. Woodcock, Per Se in Itself: How Bans Reduce Error in Antitrust 34-37 (Working Paper 2016) [hereinafter Woodcock, Per Se in Itself] (reviewing these changes); Timothy J. Muris, The New Rule of Reason, 57 ANTITRUST L.J. 859, 859-61 (1988) (reviewing these changes as applied to cases of collusion).

69 Posner, supra note 62, at 16 ("[T] he essential spirit of the Rule is to condemn only those practices that are, on balance, inefficient in the economic sense."); GAVIL ET AL., supra note 11, at 202, 207 (contrasting the per se rule and the rule of reason). 
vast swaths of conduct falling under antitrust scrutiny were subject to per se rules; today, nearly all of these have been brought under rules of reason. 70 All price fixing agreements, mergers resulting in four-firm concentration ratios in excess of at most thirty percent, tying arrangements, and resale price maintenance, to name a few of these areas, were once more or less banned outright as blatantly anticompetitive conduct.71 Today, only those price fixing arrangements that contain no additional terms that suggest a welfare-maximizing purpose remain subject to a per se rule. 72 One commentator has even suggested that all antitrust rules are now rules of reason. ${ }^{73}$

By contrast, antitrust has done nothing to reduce prices in cases in which antitrust's traditional means would leave them above cost. Firms that gain power over prices accidentally, or, to introduce another example, by fielding a superior product, are currently exempt from antitrust scrutiny. Section 2 of the Sherman Act, ${ }^{74}$ which regulates single-firm conduct, does not recognize benefitting from accidents or selling superior products as anticompetitive conduct. ${ }^{75}$ As a result, firms that acquire power in these ways can raise their prices above cost without fear of antitrust condemnation, even when condemnation and the resulting competition would drive prices to cost but not below, and therefore would be consistent with the maximization of consumer welfare. ${ }^{76}$

The case could be made that this omission represents a failure of antitrust's imagination in defining anticompetitive conduct. The firm that monopolizes because competitors are incompetent could supply expertise to those competitors, to make them competent, and the firm's

70 A stark expression of this is that Richard Posner could write in 1977 that "[t]he Rule of Reason is rarely used to decide cases," Posner, supra note 62, at 14, and Timothy Muris in 1989 that "there is only one form of analysis, the rule of reason," Muris, supra note 68, at 859.

71 See Woodcock, Per Se in Itself, supra note 68, at 34-40.

72 See HovenKamP, supra note 15, at 279 ("If the agreement is naked, it is illegal ....").

73 See, e.g., Muris, supra note 68, at 859; cf. HovENKAMP, supra note 15, at 280 ("[T] distinction between the per se rule and the rule of reason [may be treated] as soft rather than hard."). Some commentators speak as though there were a per se rule, but really mean a rule of reason. For example: "The per se rule reflects a judgment that the costs of identifying exceptions to the general rule so far outweigh the costs of occasionally condemning conduct that might upon further inspection prove to be acceptable, that it is preferable not to entertain defenses to the conduct at all." GAVIL ET AL., supra note 11, at 104; see also Nat'l Collegiate Athletic Ass'n v. Board of Regents of Univ. of Okla., 468 U.S. 85, 103-04 (1984). The rule just described is not a per se rule, but rather a rule of reason. A per se rule is a ban on conduct entered into without any balancing of costs and benefits. The point of a per se rule is to avoid collecting any information at all on the welfare effects of the conduct. See Woodcock, Per Se in Itself, supra note 68 , at 33-34.

7415 U.S.C. $\$ 2$ (2012).

75 See Verizon Commc'ns Inc. v. Law Offices of Curtis V. Trinko, L.L.P., 540 U.S. 398, 407 (2004).

$76 \mathrm{Id}$. ("To safeguard the incentive to innovate, the possession of monopoly power will not be found unlawful unless it is accompanied by an element of anticompetitive conduct."). 
refusal to do so should then count as exclusionary conduct. Similarly, the firm that sells a superior product could share the secret to that superiority with competitors, and the firm's refusal to share should therefore count as exclusionary behavior as well.77 In cases in which competition resulting from sharing would not drive prices below costs, consumers would be made better off by condemnation of exclusionary conduct of this kind. Under the old goal of promoting competition, antitrust would occasionally condemn such conduct, treating refusals to deal as exclusionary and forcing sharing. ${ }^{78}$ But, paradoxically given the gap between end and means opened up by the consumer welfare standard, under the new goal of consumer welfare maximization, antitrust has become much less willing to condemn refusals to deal, with the result that today it is virtually impossible to bring a case against the accidental or superior product monopolist, even when forced sharing would lead to at-cost pricing and benefit consumers. ${ }^{79}$

\section{B. Objections to Filling the Gap}

There are four possible reasons for which antitrust has chosen to prevent prices from falling too low but not to stop them from remaining too high. First, addressing above-cost pricing would require antitrust to adopt new means, beyond the condemnation of anti-competitive practices, to preserve consumer welfare, or at least to redefine what antitrust means by anticompetitive conduct. That has the appearance of a greater departure from tradition than did the imposition of rule-ofreason limits on condemnation of anticompetitive conduct embraced by antitrust starting in the 1970s, as traumatic as the imposition of those limits was for advocates of the old competition goal. Those limits did not thrust antitrust beyond its traditional means of regulating competition.

The second reason is the perception that antitrust cannot change its means on its own. If antitrust has only ever operated through the regulation of anticompetitive conduct defined in a particular way, even after the object of such regulation changed from the preservation of competition to the preservation of consumers, that must be because Congress has not authorized anything more. For antitrust to attack

77 For a way in which a firm could promote competition by giving control over its own production decisions to outsiders, see Woodcock, Inconsistency in Antitrust, supra note 20, at $165-66$.

78 See generally HOVENKAMP, supra note 15, at 317-22.

79 See HovenKAMP, supra note 15, at 321 ("The antitrust law requiring a dominant firm to deal with its rivals must be regarded as a severe exception to the general, and quite competitive rule, that firms should develop their own inputs and expertise and conduct their own innovation."). 
above-cost pricing would be ultra vires.

The third reason is the belief that antitrust's new goal is not to maximize consumer welfare but to maximize consumer welfare through the regulation of anticompetitive behavior. It follows that there is no gap between end and means. Some firms may be able to harm consumers without engaging in anticompetitive conduct, but that is no concern of an antitrust interested only in stopping harm to consumers caused by anticompetitive practices.

The final reason is that courts lack the administrative capability to set prices, but the only way for courts to address above-cost pricing appears to be by setting prices. According to this argument, the only way of driving down above-cost pricing, other than by setting prices, is to promote competition in the market. But when there are no anticompetitive practices to squelch, there is no way for courts to promote competition in the market. Thus there is simply nothing courts can do to address above-cost pricing, however much they might want to close the gap between end and means.

Each of these objections to addressing above-cost pricing must be rejected. The first objection has to do with tradition. The question is whether it is ethical in some sense to break with a century and a quarter of tradition by embracing new means of attaining antitrust's end. The response is that the argument proves too much. Antitrust has already embraced a radical revision of its end from that of promoting competition to that of maximizing consumer welfare. If it is improper to depart from tradition, then antitrust ought to revert to its old goal of indiscriminate deconcentration. That would have the added benefit of eliminating the gap between end and means.

The second objection is to do with law. The question is whether it is legal to embrace new means to antitrust's end. But the rejoinder is unchanged. If there is no authority in the antitrust statutes for changing antitrust's means, then it is hard to see authority either for the change in antitrust's end that has been accepted by the courts for the past thirty years, or for the limits that have been placed upon antitrust's means to bring them into conformity with that new end. No antitrust statute speaks of welfare, which, indeed, did not exist as an economic concept at the time of the passage of the Sherman Act.80 The antitrust statutes condemn such generalities as "restraints of trade" and "attempt to monopolize." 81 Even if this language may reasonably be read to condemn anticompetitive conduct of the collusive or exclusionary varieties, respectively, the statutes do not qualify their condemnation of

80 See HovenKamP, supra note 15, at 58 ("Clearly, the framers of the Sherman Act were not contemplating Pareto-efficiency when they drafted the statute, for Pareto had not yet developed it at the time the Sherman Act was passed.").

8115 U.S.C. $\$ \$ 1-2(2012)$. 
this conduct, and certainly do not expressly limit it only to cases in which consumer welfare is improved as a result, as antitrust has done in practice since the 1970s. 82

The move to consumer welfare as an end, and the imposition of limits on antitrust's means, have been accomplished not only in the absence of express statutory authority but also in direct contradiction of binding Supreme Court precedent, particularly in the area of merger law. In Brown Shoe Co. v. United States, the Court explicitly rejected total welfare, and, by extension, consumer welfare, as the end of antitrust, and affirmed competition as the sole end. ${ }^{83}$ In United States $v$. Philadelphia National Bank, the Court established a presumption against merger to shares in excess of at most thirty percent. ${ }^{84}$ The Court has retracted neither decision, but the lower courts, enforcers, and most academics ignore both, accepting instead that consumer welfare is the exclusive goal of antitrust. 85 Enforcers now generally challenge no merger unless the merger reduces the number of competitors in the market to three or fewer, because enforcers believe that challenging smaller mergers would reduce consumer welfare.86 If antitrust may

82 The absence of qualifications much troubled early antitrust courts. The condemnation of "restraints of trade," for example, might be read to condemn all contracts. See Bd. of Trade of City of Chi. v. United States, 246 U.S. 231, 238 (1918) ("But the legality of an agreement or regulation cannot be determined by so simple a test, as whether it restrains competition. Every agreement concerning trade, every regulation of trade, restrains. To bind, to restrain, is of their very essence."). The courts imposed their own qualifications, deciding on a set of practices that count as collusion and another set that count as exclusion. See HovENKAMP, supra note 15, at 211, 313-14 (listing types of conduct that count as illicitly collusive or exclusionary under the antitrust laws). This gives antitrust a common law quality. See id. at 64 ("[F]ederal courts forge[] their own set of antitrust rules through an essentially common law process in which only Sherman [and ... Clayton] Act precedents count[]."). The hallmark of the common law is that judges may change it. See Frederick Schauer, Is the Common Law Law?, 77 CALIF. L. Rev. 455, 455 (1989) ("[C]ommon law rules are not made by legislatures; they are created by courts simultaneously with the application of those rules to concrete cases.").

83 Brown Shoe Co. v. United States, 370 U.S. 294, 344 (1962) ("Congress appreciated that occasional higher costs and prices might result from the maintenance of fragmented industries and markets. It resolved these competing considerations in favor of decentralization. We must give effect to that decision.").

84 United States v. Phila. Nat'l Bank, 374 U.S. 321, 364 (1963) ("Without attempting to specify the smallest market share which would still be considered to threaten undue concentration, we are clear that $30 \%$ presents that threat.").

85 See Steven C. Salop, Question: What Is the Real and Proper Antitrust Welfare Standard? Answer: The True Consumer Welfare Standard, 22 LOY. CONSUMER L. REV. 336, 339-47 (2010) (arguing that courts and enforcers apply a consumer welfare standard throughout antitrust law).

86 See GAVIL ET AL., supra note 11, at 452-55 (observing that in practice enforcers do not look strictly at market shares in deciding whether to challenge a merger, that generally only mergers that reduce the number of competitors to three or fewer are challenged, and that a researcher might "conclude that merger decisions of the lower federal courts and the enforcement policies of the federal antitrust agencies constitute civil disobedience that ignores the commands of Supreme Court ... decisions."); Hospital Corp. of Am. v. FTC, 807 F.2d 1381, 1386 (7th Cir. 1986) (describing it as "prudent," in a merger case, "rather than resting on the very strict merger decisions of the $1960 \mathrm{~s}$, to inquire into the probability of harm to 
embrace a new goal, and limit its means accordingly, quite in the teeth of statute and Supreme Court precedent, antitrust can expand its means beyond condemnation of anticompetitive conduct to include high pricing, to further bring its means into conformity with its new end. Perhaps the authority for antitrust's change in end is thirty years of acquiescence of Congress and the Court. ${ }^{87}$ But then antitrust might reasonably embrace new means and give those two branches of government the opportunity to acquiesce again.

The third objection is that antitrust's new end is not consumer welfare generally, but consumer welfare through the traditional means of condemning anticompetitive conduct, and nothing more. But why should this be antitrust's end? If the reason is that antitrust has always been dedicated to condemning anticompetitive conduct alone, then this is just another way of stating the first and second objections, which have already been dealt with. If the reason is that antitrust is unable to engage in the price setting that appears to be required by a move beyond the condemnation of anticompetitive conduct to a condemnation of high pricing as well, then this is just the fourth objection, to which I now turn.

The fourth objection is that the only way to drive down prices other than by condemning anticompetitive conduct is to set prices directly, but courts lack the expertise to do that. 88 According to this objection, when Congress wants price regulation, Congress creates administrative agencies staffed with experts empowered to regulate rates, something Congress has not done for antitrust. 89 The rejoinder is that the proposal for filling the gap between end and means at issue in this Article, shaming firms that charge high prices, is a third way that does not require courts to set prices. To see why this third way requires courts to do nothing with which they are not already quite comfortable, an account of court practice in setting and judging prices is required.

consumers").

87 See GAVIL ET AL., supra note 11, at 454 (arguing that ignoring Supreme Court merger precedent is not civil disobedience because Congress or the Supreme Court could object if either were to wish to do so).

88 See Verizon Commc'ns Inc. v. Law Offices of Curtis V. Trinko, L.L.P., 540 U.S. 398, 408 (2004) ("[C]entral plann[ing], identifying the proper price, quantity, and other terms of dealing-[is] a role for which [courts] are ill-suited.").

89 See Town of Concord, Mass. v. Bos. Edison Co., 915 F.2d 17, 22 (1st Cir. 1990) (“' $[\mathrm{R}]$ egulation' and 'antitrust' typically aim at similar goals-i.e., low and economically efficient prices, innovation, and efficient production methods-but they seek to achieve these goals in very different ways. Economic regulators seek to achieve them directly by controlling prices through rules and regulations; antitrust seeks to achieve them indirectly by promoting and preserving a process that tends to bring them about."). 


\section{COURTS AND PRICES}

\section{A. The Judicial Setting of Prices}

Courts may be the main source of the myth that courts cannot set prices, because courts are so fond of declaring themselves lacking in the requisite expertise. 90 Despite these protestations to the contrary, courts regularly engage in one-off price setting and occasionally even in longterm supervision of prices.

Whenever courts value losses for purposes of awarding damages, courts engage in one-off price setting even if they do not always realize that is what they are doing. Damages valuation is a feature of all civil cases that result in a money judgment, and can arise from violations of a wide variety of laws, including tort, contract, and antitrust. ${ }^{91}$ Money judgments always arise from destruction of property, whether a physical object, such as a car or person, or an intangible object such as a business opportunity. When a court orders the defendant to pay damages, the court in effect forces the defendant to buy the damaged object, or at least the part of the object damaged by the defendant, from the plaintiff at a price set by the court.

It is worth noting that the prices courts set when they award damages are in fact at-cost prices. The law of remedies requires that the amount of damages return the defendant to the defendant's rightful position, meaning the position the defendant would have occupied in the absence of the damage. An equivalent formulation of the rule is that the defendant must compensate the plaintiff in an amount equal to the value of the damaged object in its best alternative use, meaning its use other than for purposes of sustaining the damages that are the subject of the case. But the value of an object in its best alternative use is just the object's opportunity cost. The law therefore requires courts to set the level of damages, and therefore the price of the object, equal to the seller's (that is, the plaintiff's) cost, which is precisely what an injunctive remedy for a duty to charge low prices would require courts to do. ${ }^{92}$

90 See, e.g., Pacific Bell Tel. v. Linkline Commc'ns, 555 U.S. 438, 1121 (2009) (arguing that a court should provide no remedy when doing so requires it "to assume the day-to-day controls characteristic of a regulatory agency"); Image Tech. Servs., Inc. v. Eastman Kodak Co., 125 F.3d 1195, 1225 (9th Cir. 1997) (reversing district court's order requiring defendant to sell at reasonable prices because " $\mathrm{t}$ ]his requirement involves the court in a matter generally considered beyond our function, namely, direct price administration").

91 See Douglas Laycock, MOdern AMERICAN REMEdies: CASES AND MATERIALS 302-05 (2012) (discussing the rule that money damages are the default remedy in any civil case).

92 See Steven Shavell, Economic Analysis of ACCident LaW 8 (1987) (“Under strict liability injurers must pay for all accident losses that they cause. Hence, injurers' total costs will equal total accident costs; and because they will seek to minimize their total costs, injurers' goal will be the social goal of minimizing total accident costs. Consequently, injurers will be induced 
Courts are not in the habit of thinking of damages valuation as judicial setting of at-cost prices in a forced exchange between plaintiff and defendant, but that is what damages valuation really is.

The character of damages valuation as price-setting in a forced exchange pierces the judicial consciousness in cases involving restitution for mistaken improvements. In a typical case, the plaintiff mistakenly builds a home on a neighbor's property. ${ }^{93}$ The plaintiff then sues for restitution of the benefit conferred, meaning the value of the house. ${ }^{94}$ The traditional rule was not to provide recovery, but courts now do so, forcing the defendant either to buy the house or sell the land upon which the house was built at a price supervised by the court. 95 Courts treat such cases as sounding in restitution, but the cases might just as easily be understood in traditional damages terms. The beneficiary of the mistaken improvement has done some bad act, such as failing to police the beneficiary's property line, causing the mistaken improver to suffer harm in the form of building on property to which the mistaken improver has no right of access. The mistaken improver sues the beneficiary in tort and obtains the purchase price of the house as damages, which represents the mistaken improver's opportunity cost.

Courts consciously engage in price setting in two other kinds of cases, which generally involve supply markets and continuing judicial supervision. The first is the FRAND case. When courts enforce contracts that require "fair, reasonable and nondiscriminatory" licensing of intellectual property inputs, sometimes called FRAND or RAND terms, they must order the defendant to license at a particular, reasonable, price. 96 The second is the occasional case in which antitrust recognizes an exception to the right of a firm to refuse to deal with competitors and accordingly forces the defendant to sell an input to the plaintiff at a reasonable price. In United States $v$. Glaxo Group Ltd., for

to choose the socially optimal level of care.").

93 See LAYCOCK, supra note 91, at 499 ("There are a surprising number of way to build your house on someone else's land.”); Somerville v. Jacobs, 170 S.E.2d 805, 813 (W. Va. 1969) ("[T]his Court holds that an improver of land owned by another, who through a reasonable mistake of fact and in good faith erects a building entirely upon the land of the owner, with reasonable belief that such land was owned by the improver, is entitled to recover the value of the improvements from the landowner and to a lien upon such property which may be sold to enforce the payment of such lien, or, in the alternative, to purchase the land so improved upon payment to the landowner of the value of the land[.]").

94 LAYCOCK, supra note 91, at 499.

95 See id. at 498 ("Many courts initially took the ... view [that o] ne who built on the land of another had no remedy, except where the landowner knew what was happening and stood by silently while the improver built.").

96 See Apple, Inc. v. Motorola Mobility, Inc., No. 11-CV-178-BBC, ${ }^{\star} 4$ (Oct. 29, 2012) (“[I]t makes sense ... for the court to determine license terms."); Microsoft Corp. v. Motorola, Inc., 795 F.3d 1024, 1056-57 (9th Cir. 2015) (affirming determination of reasonable rate); Thomas F. Cotter, Comparative Law and Economics of Standard-Essential Patents and FRAND Royalties, 22 TEX. INTELL. PROP. J. 311, 315-18 (2013). 
example, the Supreme Court ordered a defendant to license production of the bulk form of a drug on reasonable terms, observing that "[m]andatory selling on specified terms and compulsory patent licensing at reasonable charges are recognized antitrust remedies." 97

In a more recent example, the district court in Aspen Highlands Skiing Corp. v. Aspen Skiing Co. required plaintiff and defendant ski slope operators to work together to sell a joint ski ticket providing consumers access to their combined slopes. 98 This implied that the parties would need to price their contributions to the joint ticket fairly, since if one party were to demand too large a share of the value from the joint ticket by charging the other a high price for including that party's slopes in the ticket, the other would be prevented from participating in the joint ticket, in violation of the order. ${ }^{99}$ Perhaps the most famous example of judicial price setting in the refusal to deal context is the case that sundered AT\&T. To prevent the local phone companies created by the breakup from denying access to their networks to disfavored longdistance carriers, the district court handling that case supervised the terms upon which local carriers provided access to long-distance carriers for more than a decade. 100

\section{B. The Judicial Review of Prices}

\section{Outside Antitrust}

Judges have probably spent as much time deciding whether prices are too high or too low-all that would be required under the proposed duty to charge low prices-as they have setting new prices by injunction or through damages remedies. Perhaps the most important historical example of price judging was the insistence of the courts, for the halfcentury ending in 1944, upon regularly reviewing the prices set by administrative agencies, to determine whether the prices were confiscatory, and therefore in violation of the due process protections in

97 United States v. Glaxo Group Ltd., 410 U.S. 52, 56, 64 (1973). Although tried as a nonprice intrabrand restraints case, Glaxo would be a refusal to deal case today, after the demise of the per se rule in nonprice intrabrand restraints cases. See United States v. Arnold, Schwinn \& Co., 388 U.S. 365, 379 (1967) ("As the District Court held, where a manufacturer sells products to his distributor subject to territorial restrictions upon resale, a per se violation of the Sherman Act results."); Cont'l TV, Inc. v. GTE Sylvania Inc., 433 U.S. 36, 57 (1977) (overruling Schwinn and imposing a rule of reason on all nonprice intrabrand restraints).

98 See Aspen Highlands Skiing Corp. v. Aspen Skiing Co., 738 F.2d 1509, 1513 (10th Cir. 1984).

99 Id.

100 United States v. Am. Tel. \& Tel. Co., 552 F. Supp. 131, 142 (D.D.C. 1982); IIIB PhILLIP E. AREEDA \& HERBERT J. HOVENKAMP, ANTITRUST LAW, 298 n.51 (4th ed. 2015). 
the Constitution. 101 This required a determination whether prices were too low to permit regulated industries a reasonable profit. ${ }^{102}$ When the Court finally withdrew from due process review of agency price regulation, the Court did so not on the ground that courts are unable to pass judgment on prices, but in order to protect price regulators from costly second-guessing of their price determinations. ${ }^{103}$ Throughout this period, the courts were able to maintain a strict distinction between judging prices and setting them, remanding prices they judged confiscatory to the regulator to choose a reasonable price. 104

Throughout the nineteenth century, the courts also passed judgment on contract prices, first under the doctrine of consideration and then, when that went into decline, the doctrine of substantive unconscionability, which the courts still occasionally use today. ${ }^{105}$ Both

101 The case that gave rise to this was Chi., Milwaukee \& St. Paul Ry. Co. v. Minn., 134 U.S. 418,458 (1890) ("If the company is deprived of the power of charging reasonable rates for the use of its property, and such deprivation takes place in the absence of an investigation by judicial machinery, it is deprived of the lawful use of its property, and thus, in substance and effect, of the property itself, without due process of law and in violation of the Constitution of the United States ...."). The case that ended it was Power Comm'n v. Hope Gas Co., 320 U.S. 591, 602 (1944) ("[The rate order] is the product of expert judgment which carries a presumption of validity.”). See BARBARA FRIED, THE PROGRESSIVE ASSAULT ON LAISSEZ FAIRE: ROBERT Hale AND THE FirSt LAW AND ECONOMICS MOVEMENT 189 (1998) (“After Hope, the Court held to its implicit promise to retire from the field, never intervening again under a constitutional due process analysis in any public utility rate determinations ....").

102 Smyth v. Ames, 169 U.S. 466, 526, 547 (1898) (holding that a regulated firm is entitled to a "fair return").

103 This is clear from the detailed analysis of the rate base engaged in by the Court in Hope. Hope, 320 U.S. at 603-08. Although it did refer to the determinations of regulators as "expert" and entitled to a presumption of validity, the Court did not declare itself incapable of reviewing rates as an administrative matter. The progressive commentators who eventually pushed the Court out of the business of judging rates were primarily motivated by a desire to lessen the burden of litigation imposed on regulators by judicial oversight. See FRIED, supra note 101, at 190-91 ("Courts ... rarely reversed rate determinations .... [b]ut the very fact that rates were subject to judicial review ... imposed significant costs ....").

104 Newton v. Consol. Gas Co. of N.Y., 258 U.S. 165, 177 (1922) ("Rate making is no function of the courts and should not be attempted either directly or indirectly."); Osborne v. San Diego Land \& Town Co., 178 U.S. 22, 40 (1900) (agreeing with the judgment of the court below that "if the rates established by the board of supervisors were unreasonable they could only be annulled. In no case would the court fix them").

105 See Morton J. Horwitz, The Transformation of AMERICAN LAW, 1780-1860, 167, 179 (1977) (observing that eighteenth-century "[c]ourts and juries did not honor business agreements on their face, but scrutinized them for the substantive equality of the exchange," and that the "substantive doctrine of consideration" did not fall until the first quarter of the nineteenth century); Seymour v. Delancey, 3 Cow. 445, 532 (1824) (reversing denial of specific performance on ground of lack of consideration due to inadequate price and stating that "[i]nadequacy of price, unless it amount to conclusive evidence of fraud, is not itself a sufficient ground for refusing a specific performance of an agreement"); EDWARD ALLAN FARNSWORTH, CONTRACTS 303-07 (3d ed. 1999) (discussing pre-Uniform Commercial Code unconscionability cases, nearly all of which involve refusal to order specific performance of land contracts for which the purchase price was thought too low by the court) (sources cited therein); U.C.C $\$ 2-302 \mathrm{cmt} .1$ (AM. LAW INST. \& UNIF. LAW COMM’N 2014) (stating that for any contract "[ $\mathrm{t}]$ he basic test is whether, in the light of the general commercial background and 
doctrines allow a court to consider whether a price listed in a contract is fair without necessarily setting a new price as a remedy. 106

\section{Inside Antitrust}

While due process review of administrative rate decisions and meaningful application of the doctrines of unconscionability and consideration belong largely to the past, judicial review of prices remains commonplace today in several areas of antitrust. The courts pass judgment on prices in antitrust cases when they check for market power, calculate damages to be awarded to buyers, or rule on the existence of predatory pricing. Consider first the case of market power, which must be proven to establish a claim of monopolization, tying, or anticompetitive merger under the antitrust laws.107 Market power is defined as "a firm's ability to increase profits by reducing output and charging more than a competitive price for its product." 108 Although the most popular way to establish market power is to show that the defendant has a high market share, courts also accept evidence that a firm has charged a high price as evidence of market power. ${ }^{109}$ In particular, courts sometimes consult accounting statements to determine whether a firm's prices are so high that the firm is able to earn monopoly profits in the economic sense. ${ }^{110}$

The courts also pass judgment on prices at the remedies stage in

the commercial needs of the particular trade or case, the clauses involved are so one-sided as to be unconscionable under the circumstances existing at the time of the making of the contract"); Perdue v. Crocker Nat'l Bank, 702 P.2d 503, 925 n.10, 926-27 (Cal. 1985) (holding that claim that bank fee was unconscionably high under UCC $\$ 2-302$ survives a motion to dismiss).

106 A number of states have enacted price gouging statutes that punish the charging of high prices during disasters. See Michael Brewer, Planning Disaster-Price Gouging Statutes and the Shortages They Create, 72 BROOK. L. REV. 1101, 1112-16 (2006). Instances of application of these laws are scarce, but the passage of these laws nonetheless reflects confidence on the part of legislatures that courts can judge prices.

107 See HovenKamp, supra note 15, at 88-89 (discussing the role of market power in antitrust law and observing that although market power need not be shown for either firm in merger cases, "market power... is essential in merger cases" because " $[\mathrm{m}]$ ergers are condemned ... because of their propensity to create market power").

$108 \mathrm{Id}$. at 88.

109 See id. at 91 ("All other things being equal, a firm with a large market share has a greater ability to increase price profitably than a firm with a smaller share."). For example, a showing of high market shares and exclusionary conduct was enough for a court to conclude that Alcoa engaged in illegal monopolization in violation of Section 2 of the Sherman Act. United States v. Aluminum Co. of Am., 148 F.2d 416, 425, 430-31 (2d Cir. 1945) (stating that market share of about ninety percent gave Alcoa power and aggressive output expansion excluded competitors). Alcoa protested that it had not actually used its power to charge a monopoly price, but the court said "it is no excuse for 'monopolizing' a market that the monopoly has not been used to extract from the consumer more than a 'fair' profit." Id. at 427.

110 See HovenKamP, supra note 15, at 150 ("Courts have frequently acknowledged high profits as evidence that a firm has market power ...."). 
antitrust actions brought by buyers. ${ }^{111}$ In these cases, damages are calculated as the amount of the "overcharge" paid by buyers relative to the prices they would have paid in a competitive market. To calculate damages, a court must therefore determine (1) what the competitive price for the product would have been and (2) the extent to which the price actually charged exceeded the competitive price. 112 The overcharge is determined either by looking at prices before and after the defendant engaged in anticompetitive conduct, or by taking the prices charged by other firms in competitive markets as a yardstick.113 Either way, antitrust awards no damages, regardless of the blatancy of the underlying violation of antitrust law, if a high price cannot be proven. 114

The courts also pass judgment on prices when they decide predatory pricing cases. ${ }^{115}$ The courts define predatory pricing as pricing below cost if there is a dangerous probability that the defendant would be able to recoup all resulting losses in the future, after competitors have been driven out of the market by their inability to match the low prices. ${ }^{116}$ In order to decide a predatory pricing case, a court must determine whether the price charged by the defendant is below cost, an inquiry similar to that undertaken by the courts that

111 See id. at 724 ("An 'overcharge' injury is the injury suffered by a customer who paid a monopoly price for a product purchased from an illegal monopolist or cartel.”).

112 The task is actually harder than this, because the market may not be fully competitive before the illicit conduct of the defendant. In such cases, the overcharge is measured relative to the high price that was already charged in the market before the particular illicit conduct that is the object of the lawsuit. Berkey Photo, Inc. v. Eastman Kodak Co., 603 F.2d 263, 297-98 (2d Cir. 1979) ("[T]he jury clearly acted upon, what may be called the competitive price theorythat a purchaser may recover for the entire excess of the monopolist's price over that which would prevail in a competitive market. We believe that this was error, and that the true measure of damages, which we shall refer to as the wrongful conduct rule, is the price increment caused by the anticompetitive conduct...."). The fact that courts determine the overcharge increment, rather than the overcharge relative to the competitive price, is immaterial. My point is that courts are in the habit of judging whether prices are too high relative a baseline, whatever it may be.

113 See GAVIL ET AL., supra note 11, at 1139-40 (distinguishing the two approaches).

114 See Rosebrough Monument Co. v. Mem'l Park Cemetery, 666 F.2d 1130, 1145, 1147 (8th Cir. 1981) (holding that defendant cemeteries tied access to cemeteries for plaintiff burial marker business to use of defendants' foundation-pouring services in violation of Section 1 of the Sherman Act, but awarding only nominal damages because plaintiffs failed to prove the precise amount of the overcharge for pouring services); RSE, Inc. v. Pennsy Supply, Inc., 523 F. Supp. 954, 960-61, 971 (M.D. Pa. 1981) (upholding jury verdict of price fixing but striking overcharge damages due to lack of proof). Accordingly, it has sometimes been observed that antitrust's insistence that its per se rule against cartels applies regardless of the size of the cartel or the cartel's ability to influence prices is meaningless so far as private damages suits are concerned because without actual high pricing there is no overcharge and therefore no recovery may be had. See HovenKAMP, supra note 15, at 89 ("[A]lthough market power is not a requirement in most per se cases, such as price fixing, a consumer plaintiff seeking damages must generally show that there has been an 'overcharge."').

115 See generally HovenKAMP, supra note 15, at 371-72 (providing an overview of the claim).

116 Brooke Grp. Ltd. v. Brown \& Williamson Tobacco Corp., 509 U.S. 209, 222-24 (1993). 
reviewed prices in the early twentieth century due process cases. ${ }^{117}$

It should be clear from the foregoing that passing judgment on prices and even setting them is a well-established part of the business of courts, including those deciding antitrust cases. An antitrust duty to charge low prices, enforced by shame alone, would require courts to do no more than to decide whether prices are too high, and must therefore be administrable.

\section{An Antitrust Duty to Charge Cost}

If objections to filling the gap between antitrust ends and means all fail, whether those objections sound in tradition, law, or administrability, the question remains how best to structure an antitrust duty to charge low prices to fill the gap. Perhaps most importantly, the duty must require not just low prices, but prices equal to cost in the economic sense. Recall that the source of the gap is antitrust's inability to prevent above-cost, and therefore consumer-harmful, pricing by firms that have acquired monopoly power without engaging in conduct that antitrust considers anticompetitive. A duty to charge prices equal to cost in these cases would eliminate the harm to consumers, at least if firms choose to comply.

Aggrieved consumers should be able to enforce this duty by bringing a monopolization claim under Section 2 of the Sherman Act.118 To prevail and obtain one dollar, a plaintiff should be required to prove market power, just as any Section 2 plaintiff must now do. But unlike a current Section 2 plaintiff, the plaintiff alleging above-cost pricing should also be required to prove the existence of a high price at the liability stage, instead of being required to prove the existence of exclusionary conduct, as would normally be required for a plaintiff to

117 Kelco Disposal, Inc. v. Browning-Ferris Indus. of Vermont, Inc., 845 F.2d 404, 407-08 (2d Cir. 1988) (stating that "[p]rices that are below reasonably anticipated marginal cost, and its surrogate, reasonably anticipated average variable cost are presumed predatory" and that "[t]he characterization of legitimately disputed costs is a question of fact for the jury" (citation omitted)).

11815 U.S.C. $\$ 2$ (2012); Verizon Commc'ns Inc. v. Law Offices of Curtis V. Trinko, L.L.P., 540 U.S. 398, 407 (2004) ("[T]he possession of monopoly power will not be found unlawful unless it is accompanied by an element of anticompetitive conduct."). Because evidence that a firm charges above-cost prices can be used to establish monopoly power, and monopoly power is the only other element of a monopolization claim in addition to exclusionary conduct, the two elements would collapse into a single inquiry into the existence of above-cost pricing. See John B. Kirkwood, Market Power and Antitrust Enforcement, 98 B.U. L. REv. (forthcoming 2018) (manuscript at 23-25) (discussing cases in which evidence of above-cost pricing played a role in establishing market power); United States v. Grinnell Corp., 384 U.S. 563, 570-71 (1966) (listing only power and willful acquisition or maintenance thereof as the two requirements for proof of a claim of monopolization under Sherman Act Section 2). 
prevail on a Section 2 claim.119 Proving a high price would be no different from proving an overcharge today, but here that showing would be required for liability to exist rather than for damages to be proven. ${ }^{120}$ As a creature of federal antitrust law, this pricing duty would apply to all business entities. ${ }^{121}$ It would be enforceable by antitrust's traditional plaintiffs: competitors and buyers. But in practice only buyers, preferably suing as a class, 122 would be likely to bring cases, because higher prices tend to benefit rather than harm competitors in the absence of exclusionary conduct. ${ }^{123}$ To prevent abuse, prevailing plaintiffs should not be permitted to obtain the attorney fees normally awarded them by the antitrust laws. ${ }^{124}$

Finally, as discussed already in some detail, to address judicial unease with price setting, notwithstanding the courts' regular indulgence in the practice, the duty should be enforceable by nominal damages only. ${ }^{125}$ Although the duty would therefore lack the backing of powerful sanctions for its violation, there are reasons to think that the duty would still be valuable and even effective. I now to turn to these reasons.

119 See Grinnell Corp., 384 U.S. at 570-71 (listing power and willful acquisition or maintenance thereof, but not high pricing, as the two monopolization claim requirements).

120 See HovenKamP, supra note 15, at 727-32 (outlining methods of determining overcharge damages). Proving overcharge damages generally involves comparing the defendant's price with the competitive price, which is an imperfect proxy for cost. Proof that price is above cost itself, as is required to show lost profits in competitor suits, should also be permitted, and indeed would be the best form of proof of above-cost pricing. See infra note 137.

121 For a discussion of the preemptive effects of antitrust's consumer welfare standard with respect to corporate law, see Ramsi A. Woodcock, Antitrust as Corporate Governance 43-50 (2018) (unpublished manuscript).

122 See AREEDA ET AL., supra note 55, at 70 (discussing antitrust class actions).

123 See HovenKAMP, supra note 15, at 655 (observing that collusion or oligopoly, which lead to high prices without exclusionary conduct, benefit competitors, preventing them from suing because they lack "injury-in-fact"). Private antitrust suits are authorized for "[a]ny person injured in his business or property by reason of anything forbidden in the antitrust laws ...." 15 U.S.C. $\$ 15$ (2012). In accordance with antitrust's original goal of promoting competition, regardless of welfare, this language has always been held to permit suits by aggrieved competitors. HOVENKAMP, supra note 15, at 669 ("[C]ompetitor standing is so well established in antitrust case law that it is seldom questioned except when the plaintiff lacks antitrust injury."). Consumer suits are also of great vintage, but it may reflect the shift in antitrust's goal toward consumer welfare in the 1970s that all doubts about their legality were only put to rest by the Supreme Court around that time. Reiter v. Sonotone Corp., 442 U.S. 330, 342 (1979) ("The essence of the antitrust laws is to ensure fair price competition in an open market. Here, where petitioner alleges a wrongful deprivation of her money because the price of the hearing aid she bought was artificially inflated by reason of respondents' anticompetitive conduct, she has alleged an injury in her 'property' under $\$ 4$.").

124 For a discussion of the legal basis for barring recovery of attorney fees in pricing suits, see infra Section IV.C.

125 For a discussion of the legal basis for awarding nominal damages in such cases, see infra Section IV.C. 


\section{A. Efficacy}

\section{Social Pressure}

The proposed duty to charge low prices would be enforced primarily through the social pressure created by the declaration of a federal judge that a price is too high and the defendant firm has therefore unnecessarily enriched itself at the expense of the consumer. Rules that rely on social pressure for enforcement have been shown to be effective in compelling compliance with international human rights laws. Courts also already sometimes use social pressure to discipline corporate defendants. ${ }^{126}$ Despite the harm to consumer welfare inflicted by above-cost pricing, the social norm condemning above-cost pricing is weak at present. Many business people believe that the maximization of profit, the most extreme form of above-cost pricing, is the only goal of business life. ${ }^{127}$ The proposed social pricing duty would strengthen the social norm against above-cost pricing by giving that norm the dignity of law. ${ }^{128}$

\section{The Nonlinearity of Welfare in Prices}

Shame may not cause firms to drop their prices all the way to cost, but even a small reduction in prices will bring about some increase in consumer welfare, and indeed the largest possible increase in total welfare, something that should recommend a low pricing duty to the law-and-economics movement and other advocates of the maximization

126 Krain, supra note 23, at 585 ("The results suggest that naming and shaming by NGOs, the Northern media, and IOs all have significant ameliorative effects on the severity of the most extreme atrocities.").

127 See Michael C. Jensen, Value Maximization, Stakeholder Theory, and the Corporate Objective Function, 22 J. APPLIED CORP. FIN. 32, 32, 34-35 (2001) (endorsing the position of "most economists" that maximization of the value of the firm is the proper objective of management and noting that if markets are competitive this will also maximize social welfare).

128 See Robert C. Ellickson, Law and Economics Discovers Social Norms, 27 J. LEGAL STUD. 537, 540-46 (1998) ("Much of the glue of a society comes not from law enforcement, as the classicists would have it, but rather from the informal enforcement of social mores by acquaintances, bystanders, trading partners, and others. These unofficial enforcers use punishments such as negative gossip and ostracism to discipline malefactors and bounties such as esteem and enhanced trading opportunities to reward the worthy."); Melvin A. Eisenberg, Corporate Law and Social Norms, 99 COLUM. L. REV. 1253, 1269 (1999) ("Although legal standards of conduct are characteristically accompanied by liability rules or other enforcement regimes, even a legal standard of conduct that is unaccompanied by such a regime may be effective because of its impact on social norms."); Dan M. Kahan \& Eric A. Posner, Shaming White-Collar Criminals: A Proposal for Reform of the Federal Sentencing Guidelines, 42 J.L. \& ECON. 365, 385 (1999) (providing an example of a corporate board forced by the court to make a public apology as part of the remedy in an environmental litigation). 
of total welfare. Ian Ayres has pointed out that, as a matter of economic theory, a firm's first reduction in prices should generate the greatest increase in total welfare. ${ }^{129}$ It follows that even if shaming induces a firm to reduce its prices by only a small amount, that reduction could pay a substantial dividend to society as a whole. 130

Ayres's logic is this. When a firm charges a price above cost for a product, some buyers who would be able to afford the product at a price equal to cost are priced out of the market. The value lost to those consumers, net of the cost that would have been incurred by the firm in producing the units of the product that those consumers now cannot enjoy, is known as deadweight loss; it represents a loss in total welfare because the loss is not recaptured by anyone else, but instead represents production and enjoyment foregone by society as a whole.

When the firm reduces price by a small amount, the first buyers to be priced back into the market by the price reduction are those who place the highest value on the product. Those buyers were priced out to begin with only because the value they placed on the product fell slightly below the original high price charged by the firm. As a consequence, a small reduction in price brings these high-value consumers back into the market. Their return represents an elimination of part of the deadweight loss caused by the high pricing, indeed, the largest restoration of total welfare associated with any of the small steps down in price required to eventually bring price down to the level of costs. Subsequent steps down in price continue to increase total welfare by bringing additional consumers back into the market, but these new consumers increase total welfare at a lower rate because these consumers place a lower value on the product than do the initial ones. It follows that even if shaming would bring about only a very small reduction in the prices charged by firms, shaming would realize the greatest possible marginal increase in total welfare.

The prevailing antitrust legal standard requires maximization of consumer, rather than total, welfare, meaning that the standard prioritizes protection of the value enjoyed by consumers over that enjoyed by consumers and producers together as a group. It is therefore important to note that although the first small reduction in price realizes the greatest marginal total welfare improvement, the first small reduction in price does not necessarily realize the greatest marginal consumer welfare improvement. 131 Consumers still benefit from a small

129 Ayres, supra note 24, at 22.

130 See id. ("Consider a monopolist with constant marginal costs facing a linear forty-five degree demand curve.... A ten percent reduction in its markup reduces monopoly profit by less than one percent, but reduces the deadweight loss of monopoly by almost twenty percent.").

131 For the argument that antitrust is interested in consumer, rather than total, welfare, see Salop, supra note 85 . For the argument that consumer welfare is the standard that the framers 
price drop, justifying, under a consumer welfare standard, even a rule that can bring about only a small reduction in prices. The large marginal increase in total welfare associated with that small price drop is just icing on the cake.

\section{B. Enforcement Costs}

Because antitrust's goal is to maximize consumer welfare, which implies a willingness to sacrifice the total welfare of society as a whole in the interest of enriching consumers as a group, efficiency analysis of legal rules, which amounts to determining the effect of rules, inclusive of enforcement costs, on total welfare, is fundamentally incompatible with antitrust. The consumer welfare standard would itself fail an efficiency test precisely because the consumer welfare standard would sacrifice total welfare to help consumers. While antitrust rules should not be subjected to an efficiency test, there is good reason to think that the enforcement costs of the proposed duty to charge low prices, which are the costs of court administration, attorneys, and error, would not be particularly large. 132

of the Sherman Act always wanted, see Robert H. Lande, Wealth Transfers as the Original and Primary Concern of Antitrust: The Efficiency Interpretation Challenged, 34 HASTINGS L.J. 65 (1982); John B. Kirkwood \& Robert H. Lande, The Fundamental Goal of Antitrust: Protecting Consumers, Not Increasing Efficiency, 84 Notre DAME L. REV. 191 (2008).

The reason a small initial reduction in price does not necessarily result in the largest marginal increase in consumer welfare is this. The consumer welfare improvement associated with a price reduction is measured by the extra value, net of price, enjoyed by all consumers who buy the product at the reduced price, not just the value enjoyed by the additional consumers priced back into the market by the price reduction. Indeed, for a given reduction in price, each existing consumer enjoys an increase in welfare equal to the price reduction. Now, for the first initial reduction in price, only existing consumers, plus the few priced back into the market by the slightly lower price, enjoy gains from the price reduction. Those who still cannot afford the product at the new lower price enjoy no gains. But for the final reduction in price, which brings the last of those consumers formerly priced out of the market back into the market, all consumers, both existing and formerly priced out, enjoy gains from the price reduction. If the value that originally-priced-out consumers place on the product is small relative to the total number of priced-out consumers, the last price drop, not the first, could turn out to be the most fruitful from the perspective of consumer welfare. Gains from reduced prices to existing consumers would tend to account for most of the consumer welfare gains associated with each step down in price, because the low value placed on the product by originally-priced-out consumers means that bringing each of these consumers back into the market adds little to overall consumer welfare. Moreover, at the final step down in price the gains from reduced prices to existing consumers would be greatest because virtually all consumers who can afford to pay the cost of production can buy at a price just a step above cost.

132 These are the three types of costs of legal rules generally recognized in the law-andeconomics literature. See THOMAS J. MiCELI, ECONOMICS OF THE LAW: TORTS, CONTRACTS, PROPERTY, AND LITIGATION 183-86 (1997) (providing textbook frivolous litigation model that accounts for errors in adjudication, attorney fees, and filing costs, which are court administration costs). For an example of an alternative efficiency analysis that trades off 
Court administration costs and attorney fees depend on the volume of litigation. If the new duty encourages large numbers of lawsuits, court dockets will be clogged and lawyers happy. There is good reason to think that above-cost pricing is pervasive in the economy, and the number of violations of the proposed low pricing duty therefore very large, but there is no reason to think that consumers would challenge most above-cost prices under a low pricing duty. ${ }^{133}$ Because there would be no attorney fee shifting under the proposed duty, plaintiffs would find a suit worthwhile only if the gains to consumers from any price reduction that would be brought about by filing suit, discounted by the probability that the suit will fail, exceed the cost of litigating against a usually well-funded business entity. ${ }^{134}$ This is likely to save a great many above-cost prices from challenge and accordingly keep court costs and attorney fees low.

Error costs are the losses in either total or consumer welfare that result from erroneously pushing prices below cost. 135 For example, they would be the total or consumer welfare losses associated with the bankruptcy of a business that, out of fear of running afoul of a low pricing duty, were to charge a price below cost and thereby fail to generate enough revenue to pay creditors. Error costs of either the total or consumer welfare variety are unlikely for a low pricing duty because the duty would be enforced only with nominal damages. A firm that is erroneously held to engage in above-cost pricing, and would actually go out of business if it were to charge a lower price, faces a choice between ignominy and insolvency. The survival instinct is likely to induce the firm to choose the former.

Perhaps more dangerous is the scenario in which a firm might curtail investment in research and development out of fear that it would be difficult to explain to a court why such investment is necessary and should therefore be counted as a cost. The firm would not become insolvent as a result of this fear, but the firm would not create as valuable a set of products as the firm might otherwise. This possibility is not of great concern, however, because it presupposes that the threat of nominal damages and perhaps shame would actually make a firm

consumer welfare against enforcement costs, see Ramsi A. Woodcock, Uncertainty and Reverse Payments, 84 TENN. L. REV. 99, 139-41, 144-48 (2016).

133 See Elhauge, supra note 12, at 1281-82 ("A[] big economic puzzle in recent years has been why, at a time when corporate profits have been at record highs, corporations have been so reluctant to invest those profits on expanding output." (sources cited therein)).

134 See SteVEn Shavell, Foundations of Economic Analysis of LAW 390 (2004) ("The plaintiff will sue when his cost of suit is less than his expected benefits of suit.").

135 There are also offsetting error costs associated with keeping prices too high. See MiCELI, supra note 132, at 51-52 (observing that there are two types of legal error, that of "false conviction" and that of "false acquittal"). Eliminating these is precisely the goal of the proposed low pricing duty. See, e.g., supra text accompanying note 66. Accordingly, in this Section on enforcement costs, I consider only those error costs associated with pushing prices too low. 
willing to underinvest. But a firm would likely be willing to defy a judgment and nominal damages when the firm believes its high prices are necessary for investment, even if such defiance is not strictly necessary for the firm's survival.

This investment fear scenario also misinterprets the role of the courts in passing judgment on prices. The power to review a price to determine whether the price equals cost is not the power to abrogate the business judgment rule of corporate law and substitute the court's views regarding what constitutes a prudent level of investment in research and development for that of the firm. ${ }^{136}$ In deciding whether prices are above costs, a court must accept the costs chosen by the firm as given and ask only whether prices exceed them. This is akin to what a court does in predatory pricing cases, in which the court takes some measure of cost as given and decides whether price is low in relation to it. ${ }^{137}$ If firms want to game the system by increasing investment in research and development to justify higher prices, so much the better for the economy. 138

136 See Lynn A. Stout, In Praise of Procedure: An Economic and Behavioral Defense of Smith v. Van Gorkom and the Business Judgment Rule, 96 Nw. U. L. REV. 675, 675 (2001) ("The business judgment rule is perhaps best summarized as a ban against courts second-guessing the substantive quality of disinterested corporate directors' decisions.").

137 See Brooke Grp. Ltd. v. Brown \& Williamson Tobacco Corp., 509 U.S. 209, 222 (1993) (requiring proof, for a predatory pricing claim, that "that the prices complained of are below an appropriate measure of its rival's costs"). By contrast, in the overcharge context, courts generally do not bother with determining cost. The baseline for the overcharge is the market price absent the bad conduct, regardless whether that price covered the defendant's cost. See HOVENKAMP, supra note 15, at 727-32 (describing the yardstick and before-and-after measures of overcharge, both of which take a market price as a baseline and compare it to the price charged by the defendant). But courts do concern themselves with cost in the far more common case brought by a competitor, in which the measure of damages is lost profits, rather than overcharge. Profit cannot be determined without taking cost into account. See id. at 657, 734 (discussing lost profits measures of damages and describing consumer actions under the antitrust laws as "relatively infrequent" in relation to competitor actions).

138 There is such a thing as too much expenditure on research and development. See Woodcock, Inconsistency in Antitrust, supra note 20, at 133-36. But there is some evidence that actual expenditure is too low. For example, one study shows that even if firms were to spend all of their economic (quasi-) profits attributable to patents on research and development, there would still be underinvestment in research and development. Vincenzo Denicolò, Do Patents over-Compensate Innovators?, 22 ECON. POL'Y 680, 689-91, 697-98 (2007). Assuming that economic profits attributable to sources other than patents have the same length and breadth as those due to patents, and, as the objection assumes, that firms do not in fact spend all their monopoly profits on research and development, I can conclude that giving firms an incentive to justify high prices by investing more in research and development is a good thing. $C f$. W. Davis Dechert, Has the Averch-Johnson Effect Been Theoretically Justified?, 8 J. ECoN. DYNAMICS \& CONTROL 1, 1 (1984) (discussing argument that firms subject to regulate prices tend to overinvest). 


\section{The Legality of Nominal Damages and Fee Stasis}

\section{Nominal Damages}

The antitrust laws provide many remedies, but only money damages, and only nominal money damages in particular, would be permitted to remedy violations of the proposed low pricing duty. The antitrust laws allow a private plaintiff to obtain thrice actual money damages, injunctive relief, and attorney fees, while the government can obtain damages and injunctive relief, as well as disgorgement of profits, criminal fines, and imprisonment. ${ }^{139}$ Criminal penalties for violation of the proposed low pricing duty may immediately be ruled out because the government prosecutes only naked price fixing criminally. ${ }^{140}$ An assumption of this Article is, further, that to avoid the appearance of setting prices, the courts would not be willing to grant injunctive relief on a low pricing claim, the many cases in which courts already set prices notwithstanding. ${ }^{141}$ That leaves money damages.

In general, federal law allows nominal damages only if (1) the existence of damages has been proven, but (2) the magnitude of the damages cannot be ascertained with certainty, 142 a test apparently followed in a number of antitrust cases 143 and supported 144 by the Restatement (Second) of Torts, ${ }^{145}$ to which courts look in fashioning antitrust remedies. ${ }^{146}$ In a cause of action for violation of the proposed low pricing duty, it should be possible to establish the mere existence of

13915 U.S.C. $\$ 15$ (2012) (authorizing treble damages); FTC v. Mylan Laboratories, Inc., 62 F. Supp. 2d 25, 37 (D.D.C. 1999) (concluding that the FTC may obtain disgorgement); 15 U.S.C. $\$ \$ 4,15,26$; AREEDA ET AL., supra note 55, at 50-51 ("[T]he courts will forbid the continuation of illegal acts and may also force the defendant to... restore competitive conditions."); 15 U.S.C. $\$ \$ 15-16$ (2012); 15 U.S.C. $\$ \$ 1-2$ (authorizing fines of up to $\$ 100$ million for corporations and up to ten years of imprisonment for people); see id. at 47 ("A violation does not depend on the identity of the plaintiff, and it seems to trigger civil and criminal, legal and equitable, and private as well as public actions.").

140 See GAVIL ET AL., supra note 11, at 1055.

141 See supra Section III.A.

142 See McClaran v. Plastic Indus., Inc., 97 F.3d 347, 357 (9th Cir. 1995).

143 See supra note 114

144 The Restatement applies the rule only where the existence of injury is part of the claim, a condition satisfied in an action for violation of the proposed low pricing duty, for which the existence of damage is proven at the liability stage, because high prices at once harm consumers and violate the duty. RESTATEMENT (SECOND) OF TORTS $\$ 907, \mathrm{cmt}$. b-c (AM. LAW INST. 1977) ("Nominal damages are properly awarded when, although the claimant shows significant harm, its amount is not proved with sufficient certainty to entitle him to an award of compensatory damages.").

145 Id.

146 See Associated Gen. Contractors of Cal., Inc. v. Carpenters, 459 U.S. 519, 547 (1983) ("Since antitrust violations are essentially 'tortious acts,' the most apt analogy is to the common law of torts." (citation omitted)); Tex. Indus., Inc. v. Radcliff Materials, Inc., 451 U.S. 630, 634 n.5 (1981). 
above-cost prices with certainty, at least in some cases, just as the courts have left open the possibility of proving below-cost prices in predatory pricing cases, or indeed the possibility of proving monopoly power using direct evidence of above-cost pricing in regular monopolization cases. 147

But proof of the magnitude of the excess of price over cost, which is needed to measure damages and requires courts to identify the level of costs with certainty, is another matter entirely. Courts applying the antitrust laws of course regularly do award damages calculated as the excess of price above cost: that is more or less what takes place when courts award overcharge damages in run-of-the-mill antitrust cases. Thus, in principle, antitrust already recognizes that the magnitude of the excess of prices over cost can be proven with certainty. But there is reason for courts to require more certainty in the proof of low pricing duty damages than in the proof of overcharge damages. Indeed, there is reason to require so much certainty that proof of low pricing duty damages must always be inadequate and speculative, and therefore nominal damages alone appropriate as a remedy in low pricing duty cases.

The reason is that the goal of the remedy for a violation of a low pricing duty must be to ensure that consumers obtain the level of welfare that they would have obtained had the defendant charged a price equal to cost, but not a penny more. 148 The consumer welfare standard entitles consumers to no more than that level of welfare. Ensuring that damages awards meet these conditions requires that costs be determined with precision, to ensure that consumers are awarded precisely the excess of prices over cost that they were charged by the defendant, neither more nor less. Courts of course must estimate costs with a similar level of precision in every case in which they issue a money judgment, 149 but courts are nevertheless fond of treating the valuation problem in antitrust cases as uniquely difficult. ${ }^{150}$ For this reason, courts are likely to treat the level of precision required here as impossible to achieve, and only nominal damages therefore appropriate.

By contrast, nominal damages are not required in antitrust cases based on anticompetitive conduct, rather than high pricing, because

147 For predatory pricing, see supra note 137 . For proof of monopoly power, see supra note 118.

148 See HovenKAMP, supra note 15, at 711 ("The rationale for private antitrust damage actions could be either compensation or deterrence.").

149 See supra note 90.

150 AREEDA ET AL., supra note 55, at 58 ("II]t may be exceedingly difficult to show how the plaintiff's actual situation differs from what it would have been in the absence of the defendant's antitrust violation."). In recognition of this, antitrust courts require proof at a lower standard for the magnitude of injury than for the existence of injury in anticompetitive conduct cases. Story Parchment Co. v. Paterson Parchment Paper Co., 282 U.S. 555, 562 (1931). 
court awards of damages for anticompetitive conduct are always essentially punitive in character, even when not so designated. Damages for anticompetitive conduct are always essentially punitive because there is no rationale for efficient breach in anticompetitive conduct cases, no reason for which courts might want damages to equal costs in order to ensure that defendants who can generate more value from violating the law than the costs they inflict, and therefore ought to violate the law from an efficiency perspective, will have an incentive to do so. ${ }^{151}$ The courts already take the costs and benefits of conduct into account at the liability stage, in deciding whether conduct is anticompetitive under the rule of reason, so there is no need to use damages to ensure that defendants take those costs into account by themselves. At the remedies stage, antitrust's goal is only to ensure that anticompetitive conduct that harms consumers will never be profitable. ${ }^{152}$ That explains the default treble damages rule for private antitrust actions. 153 That also means that the precise amount of the damages is not important, so long as the amount is large. ${ }^{154}$ Thus damages need not be proven with the same level of certainty in anticompetitive conduct cases as in low pricing duty cases, and nominal damages are not therefore required in anticompetitive conduct cases.

\section{Fee Stasis}

Not only the lure of substantial damages, but also that of attorney fees, would be missing in low pricing duty cases. Courts usually do not award attorney fees to a party that recovers only nominal damages, even when a federal statute would award them to any prevailing party without qualification. ${ }^{155}$ The courts pretend in such cases that the

151 See GAVIL ET AL., supra note 11, at 1113 ("[T]he central issue for the court is what collection of civil remedies will correct the effects of improper conduct and reinvigorate competition in the future.").

152 See HovenKAMP, supra note 15, at 711 ("The goal of an enforcement system based on deterrence is to identify some optimal level of violations that should be eliminated, and make that level of violations unprofitable by imposing costs on prospective violators.").

153 See Ill. Brick Co. v. Illinois, 431 U.S. 720, 746-47 (1977) (electing not to apportion antitrust damages between direct and indirect purchasers based on actual harm, because the purpose of treble damages is to encourage enforcement of the antitrust law, not chiefly to compensate).

154 See supra note 150; cf. HOVENKAMP, supra note 15, at 722-23 (suggesting that the reason antitrust employs a lower standard for proof of the magnitude of damages is that calculating overcharge damages with precision is "unrealistic").

155 See Farrar v. Hobby, 506 U.S. 103, 115 (1992) (stating, in a federal civil rights action, that "[i]n some circumstances, even a plaintiff who formally 'prevails' ... should receive no attorney fees at all. A plaintiff who seeks compensatory damages but receives no more than nominal damages is often such a prevailing party"). 
amount of the plaintiff's fee is zero. ${ }^{156}$ Accordingly, a party prevailing on a low pricing claim would receive no reimbursement of fees from the losing party.

\section{CONCLUSION}

Judicial recognition of a duty to price at economic cost would help close the current gap between antitrust's end of maximizing consumer welfare in the economic sense and antitrust's inadequate means of condemning only high prices that are buttressed by anticompetitive conduct. The duty would be administrable because it would be enforced only by nominal damages and shame, as opposed to actual damages or injunctive relief, which latter would require courts to identify or set atcost prices. Although courts profess to be loath to identify and set atcost prices, they do not balk at regularly passing judgment on whether existing prices are too high. The proposed duty would ask courts to do no more than to extend their practice of judging prices to cases in which antitrust is otherwise impotent because no anticompetitive conduct can be proven. The weak character of the nominal damages remedy does not imply that a low pricing duty's effect on welfare-at least total welfarewould necessarily be small. Because the greatest gains in total welfare are achieved through the first reductions in price below monopoly levels, even a small effect on price could translate into a substantial gain in total welfare.

A duty to charge low prices, which means a duty to charge prices equal to economic cost, would not retard economic growth because rewards for innovation are properly understood to be a component of cost. A low pricing duty would do no more than return any unnecessary excesses of revenue over cost to consumers. If a court enforcing a low pricing duty is right that prices are too high, the defendant will, by definition, be able to lower prices, and perhaps be willing to do so as well, and if the court is wrong and prices are in fact not too high, no injunction will force the defendant to lower prices and thereby go bankrupt or underinvest in the business. Recognition of a low pricing duty is a first step toward taking seriously the fact, recognized by all, that no market can be perfectly competitive and therefore the regulation of anticompetitive conduct alone is insufficient for antitrust to achieve its consumer welfare goal. That first step is to ask firms to do the right thing.

156 See LAYCOCK, supra note 91, at 488, 698. 